\title{
Some recent studies on glass/glass-ceramics for use as sealants with special emphasis for high temperature applications
}

\author{
G. P. Kothiyal ${ }^{\mathrm{a},{ }^{*}}$, Madhumita Goswami ${ }^{\mathrm{a}}$, Babita Tiwari ${ }^{\mathrm{b}}$, Kuldeep Sharma ${ }^{\mathrm{a}, \mathrm{c}}$, \\ A. Ananthanarayanan ${ }^{\mathrm{a}, \mathrm{c}}$, Lionel Montagne ${ }^{\mathrm{c}}$ \\ ${ }^{a}$ Glass and Advanced Ceramics Division, Bhabha Atomic Research Centre, Mumbai-400085, India \\ ${ }^{b}$ Technical Physics Division, Bhabha Atomic Research Centre, Mumbai-400085, India \\ ${ }^{c}$ Université Lille Nord de France, UCCS - Unité de Catalyse et Chimie du Solide - UMR CNRS 8181, Ecole \\ Nationale Supérieure de Chimie de Lille, Université des Sciences et Technologies de Lille, BP 108, 59562 \\ Villeneuve d' AscqCedex, France
}

Received March 26, 2012; Accepted April 5, 2012

(C) The Author(s) 2012. This article is published with open access at Springerlink.com

\begin{abstract}
Glass-ceramics owing to a combination of useful properties such as tuneable thermal expansion coefficient (TEC), good mechanical durability and chemical inertness find widespread uses in a variety of applications including seals and coatings. Glass-ceramic-to-metal seals have been fabricated with various silicate, phosphate and borate based oxide glasses depending upon the intended application. In this article, we review our studies on various glass and glass-ceramics materials development with a view to understand bonding behaviour with metals/alloys at ambient and high temperatures through a comprehensive structure property correlation investigations. Detail studies on $\mathrm{BaO}-\mathrm{CaO}-\mathrm{Al}_{2} \mathrm{O}_{3}-\mathrm{B}_{2} \mathrm{O}_{3}-\mathrm{SiO}_{2}$ (BCABS), barium strontium alumino-silicate, and strontium alumino-silicate with different additives (like $\mathrm{Nd}_{2} \mathrm{O}_{3}, \mathrm{La}_{2} \mathrm{O}_{3}, \mathrm{NiO}, \mathrm{TiO}_{2}, \mathrm{~V}_{2} \mathrm{O}_{5}, \mathrm{ZrO}_{2}, \mathrm{Cr}_{2} \mathrm{O}_{3}$, and $\mathrm{P}_{2} \mathrm{O}_{5}$ ) and barium/strontiun zinc silicate (B/SZS) glass-ceramics for high temperature sealing. We shall illustrate the role of various thermo-physical and structural characterization techniques that allowed optimum selection of materials and processing parameters. We particularly highlight the complementary role of NMR and XRD in studying the material at the short range and long range length scales.
\end{abstract}

Key words: crystallization; sintering; glass-ceramics; solid oxide fuel cells; NMR

\section{Introduction}

Glass-ceramics are a kind of polycrystalline materials formed by controlled crystallization of parent glasses

* Corresponding author.

E-mail: gpkoth@barc.gov.in
[1-4]. These materials consist of polycrystalline regions 'growing' in a matrix of residual glass [5]. Glass-ceramics display a large number of useful properties that include high chemical durability, resistance to thermal and mechanical shocks and the possibility of tuneable thermal expansion coefficient (TEC) [6-8]. As a result, glass-ceramics find wide ranging application in cookware, telescope mirror 
supports, hermetic sealing, etc [9-12]. The thermophysical properties of glass-ceramics are a function of not only the composition but also the crystallization heat treatment. Therefore, for various applications, the compositions, nucleating agents (to crystallize the desired phases) and heat treatments must be judiciously optimized to obtain materials with the necessary thermo-physical properties. In this article we review sealing of glass-to-metal/alloy and glassceramics-to-metal/alloy with a focus on some recent sealing glass-ceramic development [1-3,11-13]. One of the recent applications of glass-ceramics, which places great demand on materials performance, is sealing of solid oxide fuel cells (SOFCs) using glass/glassceramics, to effectively channel fuel and oxidant (commonly air) [14-20]. SOFC based power generation presents many advantages, including higher efficiency, lower environmental impact and ability to co-generate heat from the exhaust gas to name a few, as compared to conventional power generation [21-28]. The glass-ceramics used for sealing must show good matching of thermal expansion coefficient (TEC) with other SOFC components, low reactivity with other fuel cell components and long term stability at elevated temperature in either oxidizing or wet reducing atmosphere [21,29,30-33]. Achieving a sealant that fulfils these conditions is important to long term stability of SOFC stacks. Most SOFC sealants reported so far have been based on the alkaline earth aluminosilicate system such as barium alumino-silicate due to good thermal expansion matching and the ability to wet materials such as the interconnect allowing good sealing $[21,29,30,31,33,34]$. While the chemical durability of these glass-ceramics is generally good, it is necessary to further improve phase stability, crystallization behaviour and adhesion behaviour of the glass-ceramics with other SOFC components. Therefore, it is of interest to study the effect of various additives such as $\mathrm{TiO}_{2}$ (BCABS-T), $\mathrm{ZrO}_{2}$ (BCABS-Z), $\mathrm{Cr}_{2} \mathrm{O}_{3}$ (BCABS-Cr), and $\mathrm{P}_{2} \mathrm{O}_{5}$ (BCABS-P) in the $\mathrm{BaO}-\mathrm{CaO}-\mathrm{Al}_{2} \mathrm{O}_{3}-\mathrm{B}_{2} \mathrm{O}_{3}-\mathrm{SiO}_{2}$ (BCABS) system in order to tune viscosity, crystallization and adhesion behaviour. The effect of these additives on thermophysical and structural properties was studied using micro-hardness (MH) measurements, thermomechanical analysis (TMA), differential thermal analysis (DTA), scanning electron microscopy (SEM), magic angle spinning nuclear magnetic resonance (MAS-NMR) spectroscopy and sealing studies. Seals fabricated were tested for prolonged periods in simulated SOFC conditions and material performance was evaluated.

Based on preliminary studies, further investigations were carried out to evaluate the effect of systematic addition of $\mathrm{P}_{2} \mathrm{O}_{5}$ to the $\mathrm{BCABS}$ and evaluate the attendant effects of this on structure property correlations using MAS-NMR, SEM, sealing studies and sintering studies using hot stage microscopy (HSM). The role of $\mathrm{P}_{2} \mathrm{O}_{5}$ and the optimum quantity necessary for sealing are discussed in light of the various experiments carried out on these materials. In addition to these, we also discuss studies carried out on potential SOFC sealants belonging to the barium/ strontiun zinc silicate $(\mathrm{B} / \mathrm{SZS})$ glass-ceramic system. In order to limit the size of the article, we focus upon the materials themselves and do not discuss the details of sealing, which is beyond the scope of this article. We direct the reader to the excellent monograph by Donald [4] for further details on the science of sealing. The present article is laid out as follows.

Glass-ceramics as SOFC sealants: (a) Effect of various additives in the BCABS system, (b) Effect of $\mathrm{P}_{2} \mathrm{O}_{5}$ on structure, thermo-physical and sealing properties of BCABS glasses, (c) Sealants based on barium/strontiun zinc silicate (B/SZS) glass-ceramics, (d) Crystallization kinetics of SZS glasses, (e) Effect of various additives in the SZS system.

All the glasses discussed in this paper have been prepared by the melt quench technique followed by annealing to relieve the thermal stresses and ceramized by controlled heat treatment $[2,13]$. We briefly mention the preparation technique of each material during the relevant discussion.

\section{Effect of various additives in the BCABS system}

Driven by the need for acceptable degradation behaviour in wet reducing and oxidizing environments, alkaline earth-boro-silicate based glasses are widely accepted as the choice for SOFC sealing [34-36]. However, long term stability, the interaction behaviour and wetting properties of the sealant with various SOFC components must be optimized. Therefore, various additives have been incorporated into the glasses and their attendant effects on thermo-physical physical properties have been evaluated. The structural changes responsible for these have been studied using a combination of TMA, XRD and SEM. The basic 
composition is an alkaline earth silicate aluminosilicate glass with various additives, which can be expressed as $35 \mathrm{BaO}-15 \mathrm{CaO}-5 \mathrm{Al}_{2} \mathrm{O}_{3}-8 \mathrm{~B}_{2} \mathrm{O}_{3}-35 \mathrm{SiO}_{2}$ $2 \mathrm{M}$ (where $\mathrm{M}=\mathrm{P}_{2} \mathrm{O}_{5}, \mathrm{Cr}_{2} \mathrm{O}_{3}, \mathrm{TiO}_{2}$ or $\mathrm{ZrO}_{2}$ ).

The $\mathrm{B}_{2} \mathrm{O}_{3} / \mathrm{SiO}_{2}$ ratio of the glasses prepared was 0.22 , which falls in the required range for good wetting behaviour with interconnect materials and 8YSZ electrolyte [37]. $\mathrm{BaO}$ and $\mathrm{CaO}$ have been added to reduce the glass transition temperature and allow softening at a low enough temperature to allow sealing. $\mathrm{Al}_{2} \mathrm{O}_{3}$ has been incorporated into the glasses in order to enhance glass stability during melt quenching as described in the literature [38].

Annealed glass samples were used for thermomechanical analysis in order to evaluate the thermal expansion coefficient, glass transition temperature and the dilatometric softening temperature $\left(T_{\mathrm{ds}}\right)$. The crystallization behaviour of the glasses was studied using DTA, the details of which are reported by us elsewhere $[1,3,13,39]$.

Table 1 summarizes the thermo-physical properties of the glasses prepared. All the glasses prepared showed $T_{\mathrm{g}}$ values in the range of $600{ }^{\circ} \mathrm{C}$ to $635^{\circ} \mathrm{C}$, with TEC in the range of $11 \times 10^{-6} /{ }^{\circ} \mathrm{C}$ to $13 \times 10^{-6} /{ }^{\circ} \mathrm{C}$, indicating their suitability as sealant materials. The DTA curves for the samples are depicted in Fig. 1. The base glass (sans additives) and those with additives as well show no pronounced exothermic behaviour indicating slow crystallization kinetics. The only exception is the BCABS-Cr sample, which exhibits a strong exotherm at $\sim 725^{\circ} \mathrm{C}$. The glass transition temperatures extracted from the DTA curves are in good agreement with those obtained from TMA. This would seem to indicate that particle migration for crystallization is easier in the $\mathrm{Cr}_{2} \mathrm{O}_{3}$ containing glasses, which is consistent with its role as a network modifier [36]. However, this also means that the conductivity of this sample is the highest as shown in the Arrhenius plot presented in Fig. 2. Also evident in Fig. 2 is a decrease in activation energy for conduction in this sample above $650{ }^{\circ} \mathrm{C}$, which is within the acceptable range for SOFC application.

The main motive behind the inclusion of additives was that the base glass shows poor interaction with 8YSZ ceramic (Fig. 3a). Figure $3 \mathrm{~b}$ shows the BCABS-P interface with 8YSZ. The interface appears continuous and a reaction zone is evident indicating intimate interaction between the BCABS-P glass and the $8 \mathrm{YSZ}$ ceramic. Similar continuous interfaces were
Table 1 Thermo-mechanical parameters for BCABS glass samples with various additives

\begin{tabular}{ccccc}
\hline Samples & $\begin{array}{c}\text { TEC }(30-500) \times \\
10^{-6} /{ }^{\circ} \mathrm{C}\end{array}$ & $\begin{array}{c}T_{\mathrm{g}} \\
\left({ }^{\circ} \mathrm{C}\right)\end{array}$ & $\begin{array}{c}T_{\mathrm{d}} \\
\left({ }^{\circ} \mathrm{C}\right)\end{array}$ & $\begin{array}{c}\text { Microhardness } \\
(\mathrm{GPa})\end{array}$ \\
\hline $\begin{array}{c}\text { BCABS } \\
\text { (without }\end{array}$ & 11.9 & 619 & 665 & 5.68 \\
$\begin{array}{c}\text { substituent) } \\
\text { BCABST }\end{array}$ & 11.58 & 629 & 669 & 5.60 \\
BCABSP & 12.04 & 641 & 660 & 5.39 \\
BCABSZ & 12.81 & 652 & 670 & 5.74 \\
BCABSCr & 11.34 & 632 & 678 & - \\
\hline
\end{tabular}

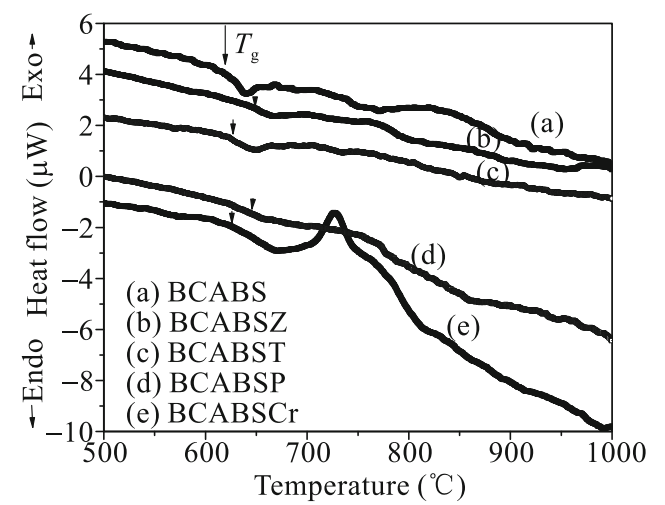

Fig. 1 TA plots of BCABS glasses containing different additives

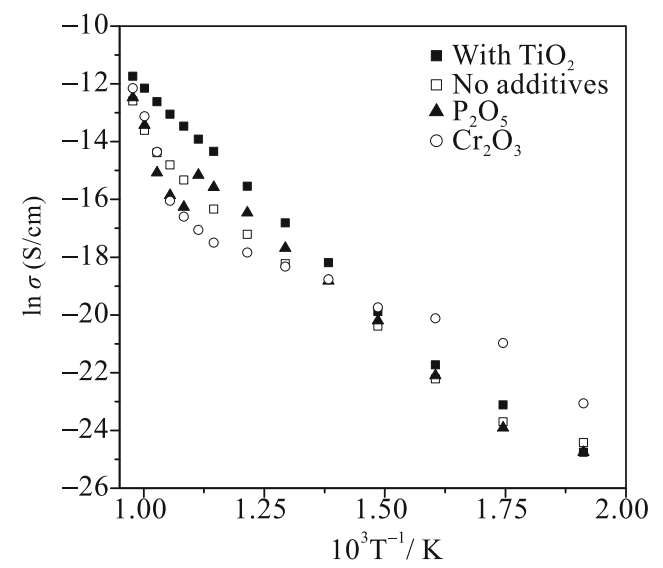

Fig. 2 Arrhenius plot for BCABS glasses containing different additives

observed in case of BCABS-Cr and BCABS-T samples. However, in case of the BCABS-Z samples, the glass shows poor interaction behaviour with the $8 \mathrm{YSZ}$ ceramic and the overall wettability is unsatisfactory as evident in Fig. 3d. A more detailed study of the element diffusion profiles for these materials is discussed in a separate publication. Therefore, we conducted further interaction studies with Crofer-22 APU alloy using only BCABS-P, BCABS-Cr and BCABS-T samples. 


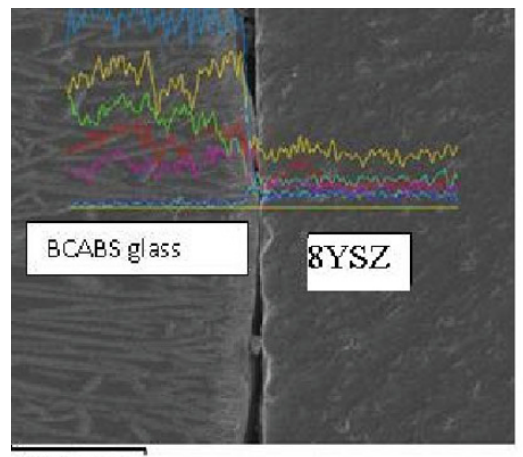

(a)

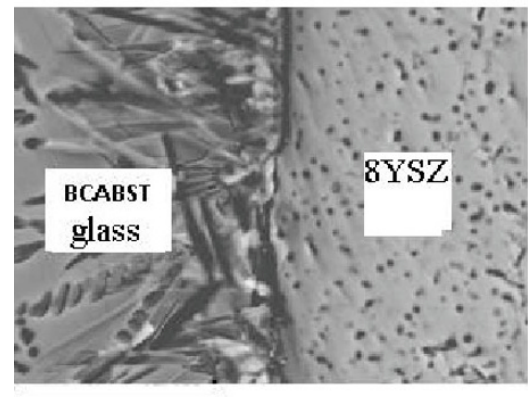

$20 \mu \mathrm{m}$

(c)

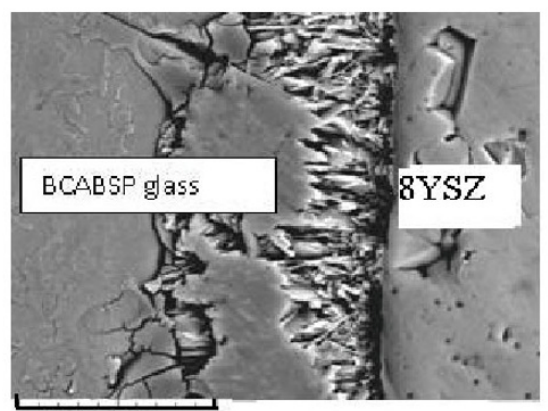

$20 \mu \mathrm{m}$

(b)

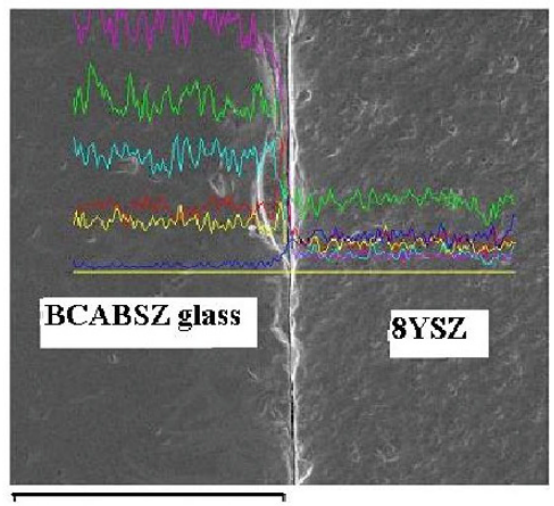

$200 \mu \mathrm{m}$

Fig. 3 Microstructure at the interfaces of BCABS glass samples with 8YSZ electrolyte with (a) BCABS, (b) BCABS-P, (c) BCABS-Cr and (d) BCABS-T

Figures $4 \mathrm{a}, 4 \mathrm{~b}$ and $4 \mathrm{c}$ show the interfaces of BCABS-P, BCABS-Cr and BCABS-T glasses bonded with Crofer-22 APU alloy interconnect materialand and heat treated at $775{ }^{\circ} \mathrm{C}$ for $300 \mathrm{~h}$. The temperature was chosen using high temperature optical microscopy. In all cases, a continuous interface is clearly evident. The formation of a $\mathrm{Cr}$ rich layer about 3-5 $\mu \mathrm{m}$ thick is also evident in these micrographs. We shall demonstrate that in case of the BCABS-P glass-ceramics, this layer could help bonding the glass-ceramic to the metal.

The phase emergence in BCABS-P, BCABS-Cr and BCABS- $T$ after heat treating at $775{ }^{\circ} \mathrm{C}$ for $300 \mathrm{~h}$ is presented in Fig. 5. In case of the BCABS-P sample, the phases formed are a mixture of $\mathrm{Ba}_{3}\left(\mathrm{PO}_{4}\right)_{2}$ and $\mathrm{Ba}_{2} \mathrm{Al}_{2} \mathrm{Si}_{2} \mathrm{O}_{8}$. This latter phase undergoes a polymorphic transition near $300{ }^{\circ} \mathrm{C}$ accompanied nearly $4 \%$ change in volume and can present problems with seal integrity under thermal cycling [41]. Therefore we have carried out an optimization study to evaluate the amount of $\mathrm{P}_{2} \mathrm{O}_{5}$ that can be added to the $\mathrm{BCABS}$ glasses which we present subsequently. In case of $\mathrm{BCABS}-\mathrm{Cr}, \mathrm{BaCrO}_{4}$ is evident in addition to the other phases and the high TEC of this phase can be detrimental to seal integrity as well. Of the materials studied, $\mathrm{TiO}_{2}$ incorporation shows the best combination of phases formed with a $\mathrm{Ba}_{1.55} \mathrm{Ca}_{0.45} \mathrm{SiO}_{4}$ and $\mathrm{BaSi}_{2} \mathrm{O}_{5}$. The thermo-physical properties of these glass-ceramics are collated in Table 2.

Despite the formation of phases that can cause problems with seal integrity, BCABS-P and BCABS$\mathrm{Cr}$ samples remained hermetic even after holding at $775{ }^{\circ} \mathrm{C}$ for upto $300 \mathrm{~h}$. Since the conductivity of the $\mathrm{Cr}_{2} \mathrm{O}_{3}$ sample is higher, we decided to investigate further the potential of $\mathrm{P}_{2} \mathrm{O}_{5}$ as an SOFC sealant.

Table 2 Thermal expansion coefficient as a function of dwell time at $775{ }^{\circ} \mathrm{C}$ for BCABS samples with different substituents

\begin{tabular}{|c|c|c|c|c|}
\hline \multirow{2}{*}{ Sample } & Base glass & $10 \mathrm{~h}$ & $100 \mathrm{~h}$ & $300 \mathrm{~h}$ \\
\hline & \multicolumn{4}{|c|}{$\operatorname{TEC}(30-300) \times 10^{-6} /{ }^{\circ} \mathrm{C}$} \\
\hline BCABST & 11.34 & 11.59 & 11.67 & 11.02 \\
\hline BCABSP & 11.85 & 11.82 & 11.43 & 10.96 \\
\hline BCABS $\mathrm{Cr}$ & 10.94 & 11.62 & 10.95 & 10.94 \\
\hline
\end{tabular}




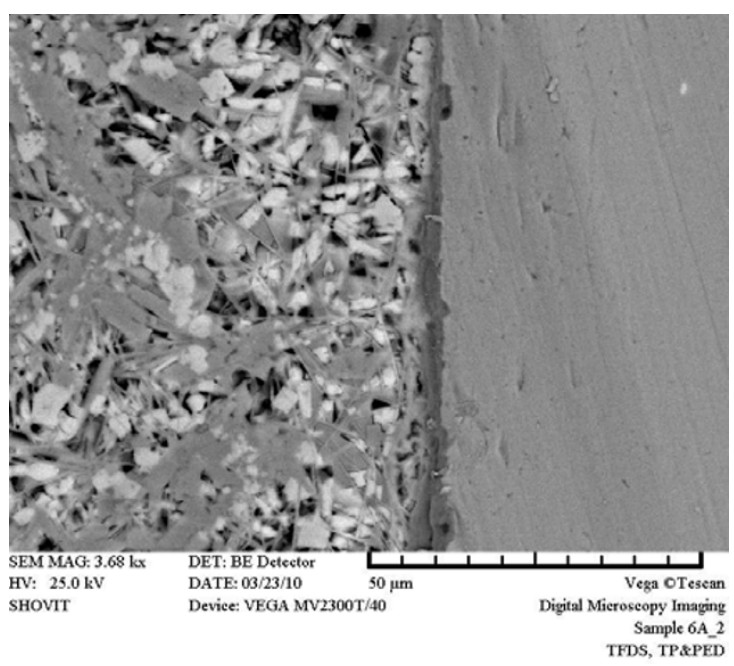

(a)

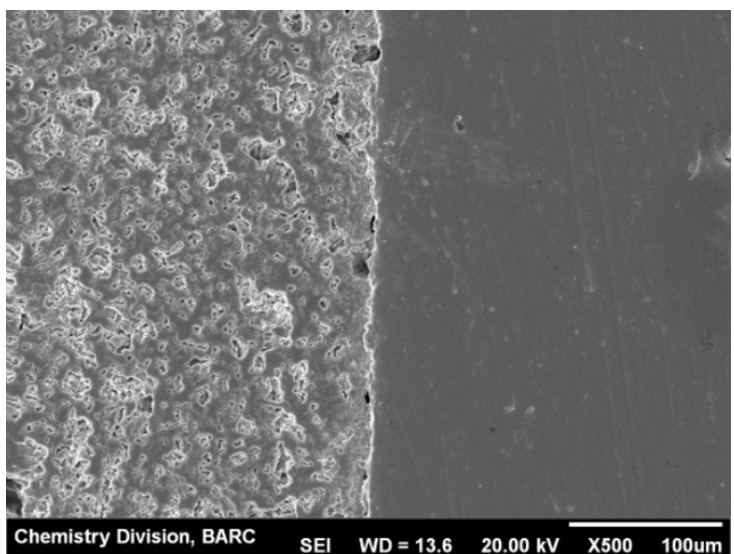

(b)

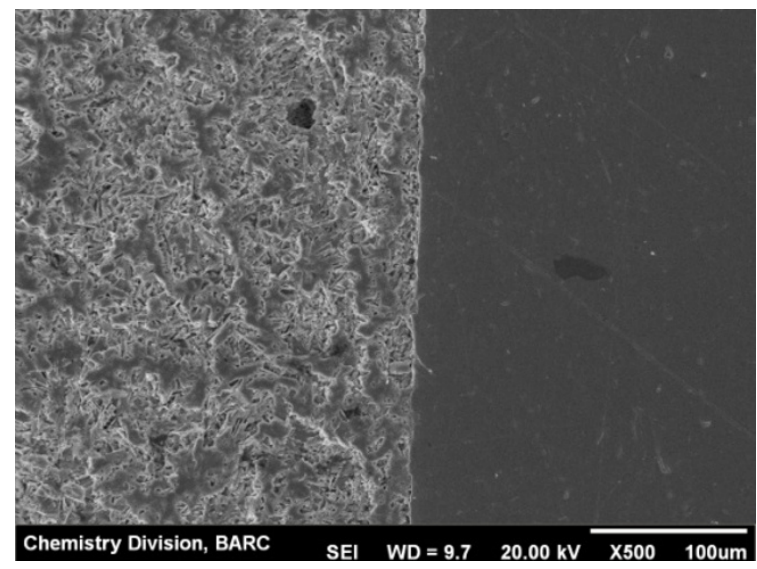

(c)

Fig. 4 Microstructure of the interfaces of BCABS glass samples bonded with Crofer 22 APU and heat treated at $775^{\circ} \mathrm{C}$ for $300 \mathrm{~h}$; (a) BCABS-P, (b) BCABS-Cr and (c) BCABS-T

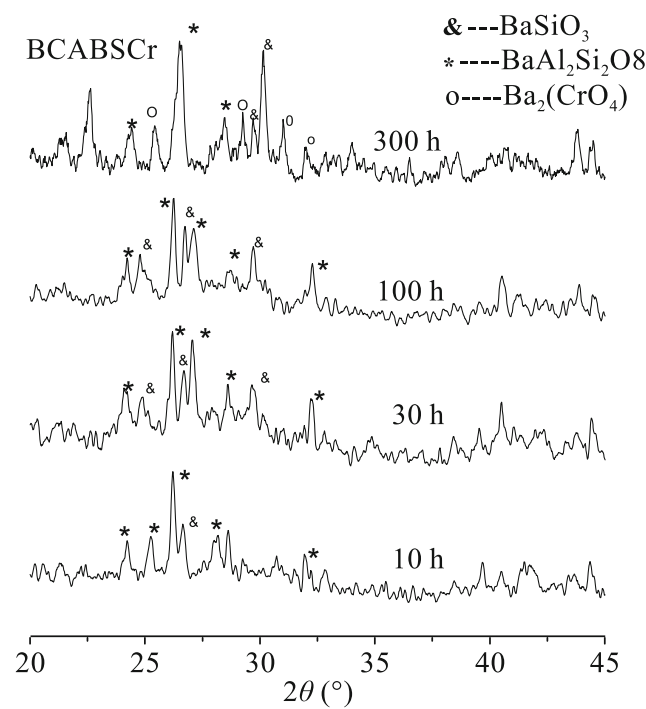

(a)

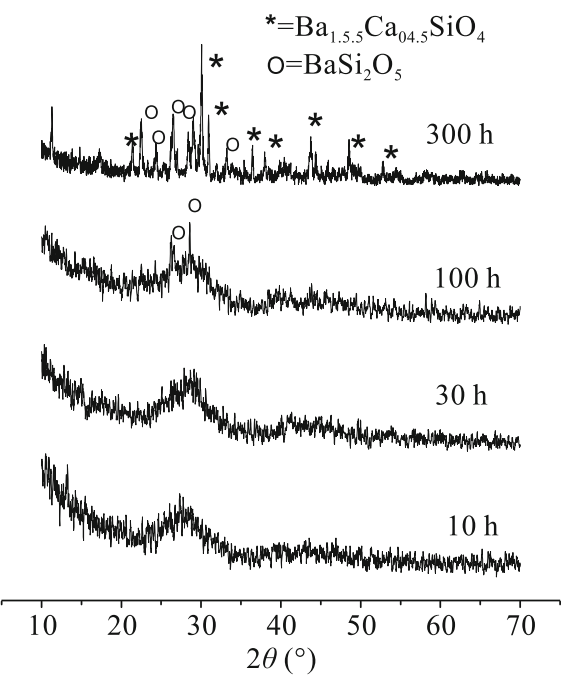

(b)

BCABSP
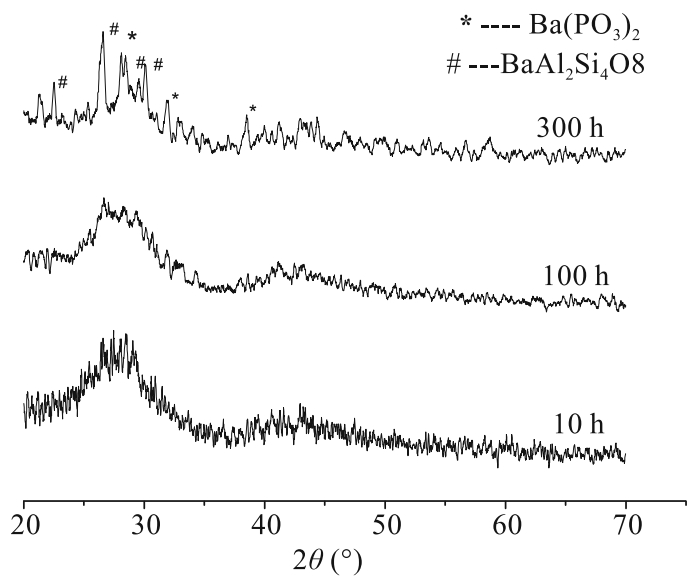

(c)

Fig. 5 Phase emergence in (a) BCABS-P, (b) BCABS-Cr and (c) BCABS-T after heat treatment at $775{ }^{\circ} \mathrm{C}$ for $300 \mathrm{~h}$ 


\section{Effect of $\mathrm{BO}_{5}$ on structure, thermo-phy- sical and sealing properties of $\mathrm{BCABS}$ glasses}

In order to investigate the effect of $\mathrm{P}_{2} \mathrm{O}_{5}$ on the structure and thermo-physical properties of the BCABS glasses, glasses with the general composition $35 \mathrm{BaO}-15 \mathrm{CaO}-5 \mathrm{Al}_{2} \mathrm{O}_{3}-8 \mathrm{~B}_{2} \mathrm{O}_{3}-(35-x) \mathrm{SiO}_{2}-\mathrm{P}_{2} \mathrm{O}_{5}$ were prepared $(0 \leqslant x \leqslant 5)$. The samples are nomenclature BCABS- $x \mathrm{P}$ where $x$ is the molar percentage of $\mathrm{P}_{2} \mathrm{O}_{5}$ incorporated. The thermo-physical properties of the parent glasses prepared by melt quenching and subsequent annealing are presented in Table 3 . The $T_{\mathrm{g}}$ values of the parent glasses are observed to increase slightly with $\mathrm{P}_{2} \mathrm{O}_{5}$ incorporation. $T_{\mathrm{ds}}$ is also augmented by $\mathrm{P}_{2} \mathrm{O}_{5}$ incorporation with a large increase observed for $5 \mathrm{~mol} \% \mathrm{P}_{2} \mathrm{O}_{5}$ incorporation. The TEC of the parent glasses reduces slightly till BCABS-4P. However, the TEC of BCABS-5P is significantly lower than the other glasses.

The DTA traces of the samples are presented in Fig. 6. All samples show a glass transition at $\sim 635^{\circ} \mathrm{C}$, and a broad crystallization exotherm centred on $730{ }^{\circ} \mathrm{C}$. In addition, the samples BCABS-OP and BCABS-4P show a second broad exotherm around $850{ }^{\circ} \mathrm{C}$ and $875{ }^{\circ} \mathrm{C}$ respectively. The crystallization behaviour observed with DTA did not show significant changes with increasing $\mathrm{P}_{2} \mathrm{O}_{5}$ concentration.

The variation in the thermo-physical properties of the glasses is attributed to increasing polymerization of the silica species as observed in the ${ }^{29} \mathrm{Si}$ NMR spectra presented in Fig. 7. The addition to $\mathrm{P}_{2} \mathrm{O}_{5}$ removes alkaline earth cations from the silicate network for charge compensation according to Eq. (1).

Table 3 Thermo-Physical properties of BCABS glasses and glass-ceramics (GC)

\begin{tabular}{lccc}
\hline & $\begin{array}{r}\mathrm{CTE} \times 10^{-6}{ }^{\circ} \mathrm{C}^{-1} \\
( \pm 5 \%)\end{array}$ & $\begin{array}{r}T_{\mathrm{g}} \pm 2 \\
\left({ }^{\circ} \mathrm{C}\right)\end{array}$ & $\begin{array}{c}T_{\mathrm{d} \pm} \pm 2 \\
\left({ }^{\circ} \mathrm{C}\right)\end{array}$ \\
\hline BCABS-0P & 11.8 & 635 & 674 \\
BCABS-0P GC & 12.5 & 597 & 875 \\
BCABS-1P & 11.6 & 638 & 673 \\
BCABS-1P GC & 12.2 & 593 & 897 \\
BCABS-2P & 11.5 & 641 & 675 \\
BCABS-2P GC & 11.8 & 622 & 896 \\
BCABS-3P & 11.4 & 642 & 677 \\
BCABS-3P GC & 12.1 & 604 & 923 \\
BCABS-4P & 11.2 & 646 & 677 \\
BCABS-4P GC & 12.3 & 602 & 928 \\
BCABS-5P & 9.9 & 653 & 683 \\
BCABS-5P GC & 11.3 & 607 & 943 \\
\hline
\end{tabular}

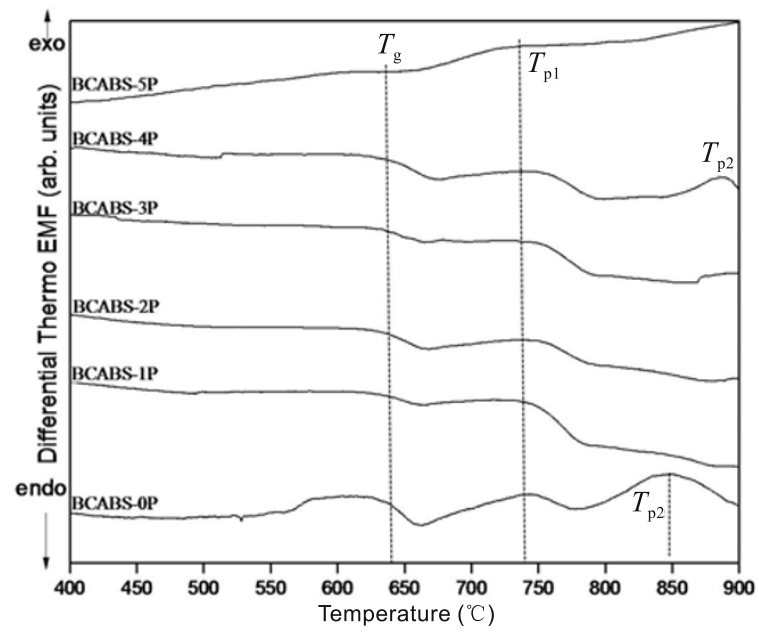

Fig. 6 DTA curves of BCABS glasses containing $0-5 \mathrm{~mol} \% \mathrm{P}_{2} \mathrm{O}_{5}$ (bottom to top)

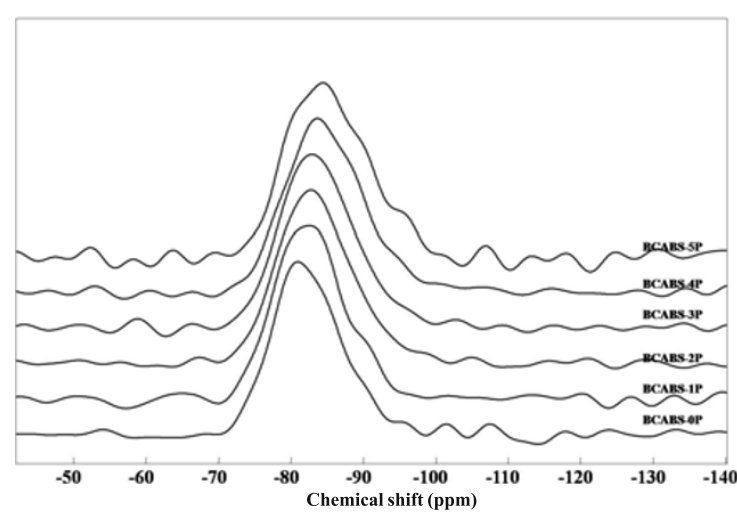

Fig. $7{ }^{29} \mathrm{Si}$ MAS-NMR spectra of BCABS-0P to 5P glasses. Note the increasing network polymerization of the glasses with $\mathrm{P}_{2} \mathrm{O}_{5}$.

where $\mathrm{M}=\mathrm{Ba}, \mathrm{Ca}$

$$
\mathrm{P}_{2} \mathrm{O}_{5}+6 \mathrm{MO} \rightarrow 2 \mathrm{M}_{3} \mathrm{PO}_{4}
$$

Simultaneously, the incorporation of $\mathrm{P}_{2} \mathrm{O}_{5}$ converts $\mathrm{BO}_{3}$ structural units into $\mathrm{BO}_{4}^{-}$according to the following reaction [30].

$$
6 \mathrm{BØO}_{2}^{2-}+\mathrm{P}_{2} \mathrm{O}_{5} \rightarrow 6 \mathrm{BØ}_{4}^{-}+2 \mathrm{PO}_{4}{ }^{3-}
$$

where $\varnothing$ denotes bridging oxygen. This leads to an increase in the relative $\mathrm{BO}_{4}$ fraction as observed in ${ }^{11} \mathrm{~B}$ MAS-NMR spectra (Fig. 8). Since the glasses have large fractions of modifying cations, these can charge compensate both the $\mathrm{PO}_{4}{ }^{3-}$ and $\mathrm{BØ}_{4}^{-}$anions. The relative increase of the more rigidly bonded, tetrahedral $\mathrm{BO}_{4}$ units as compared to the planar $\mathrm{BO}_{3}$ units also contributes to increased flow temperature, reduced TEC and increased $T_{\mathrm{g}}$ for parent glasses.

It may be emphasized that the modifier cations required for reactions 1 and 2 are removed predominantly from the silicate network. As a result, 


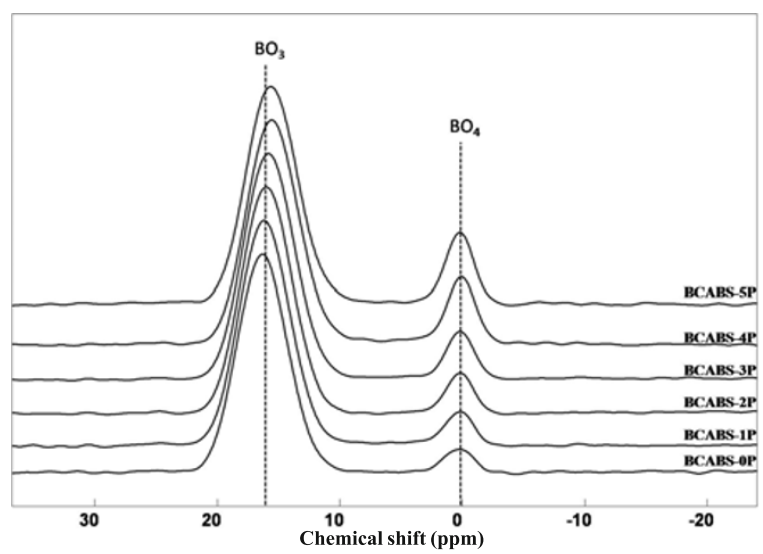

Fig. $8{ }^{11} \mathrm{~B}$ MAS-NMR spectra of BCABS-0P to 5P glasses

the $\mathrm{Al}$ coordination remains primarily tetrahedral (Fig. 9). However, the $\mathrm{Al}^{(4)}$ resonance is systematically displaced to lower chemical shift values with increasing $\mathrm{P}_{2} \mathrm{O}_{5}$. The shift can be attributed to changes in the silicate network polymerization which can cause a change in the Al second neighbour coordination sphere. In addition, this can also be attributed to $\mathrm{AlO}_{4}$ being increasingly charge compensated by $\mathrm{Ba}^{2+}$ (field strength 0.26) instead of $\mathrm{Ca}^{2+}$ (field strength 0.36), since the latter would be preferred for charge compensation of $\mathrm{PO}_{4}{ }^{3-}$ units [40]. However, we expect the polymerization change in the silicate network to be the dominant contributor for the displacement of the $\mathrm{Al}$ resonance.

Since sealing requires high densification of the glass upon sintering, maximum shrinkage must be attained before the beginning of crystallization. With increasing $\mathrm{P}_{2} \mathrm{O}_{5}$ fraction, crystallization becomes more prevalent, thus reducing the maximum shrinkage

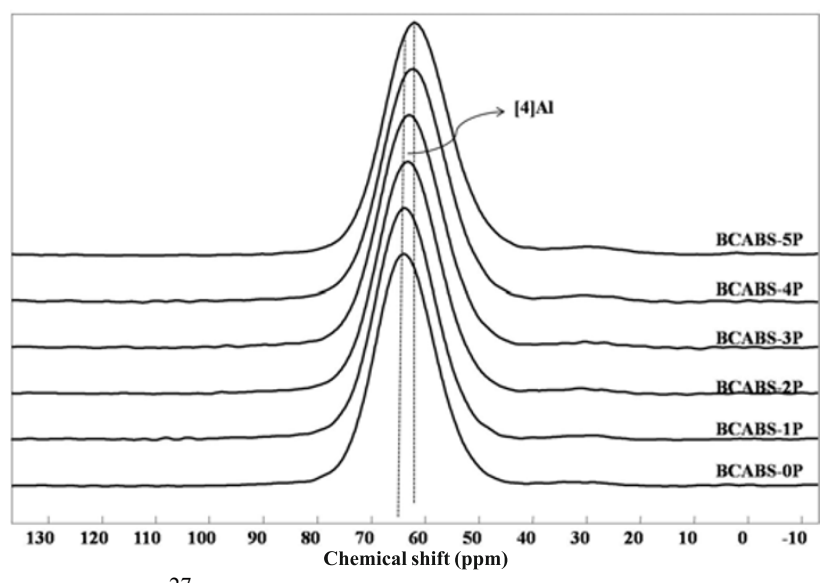

Fig. $9{ }^{27} \mathrm{Al}$ MAS-NMR spectra of BCABS-0P to $5 \mathrm{P}$ glasses exhibiting $\mathrm{Al}$ in tetrahedral coordination attainable as seen by Hot Stage Microscopy (HSM) experiments [41]. This also leads to a plateau in normalized area prior to sample melting, followed by a sharp reduction in normalized area at the flow temperature, which is typical of the melting of crystalline materials [41]. The poor sintering property of BCABS-4P and 5P, combined with relatively high flow temperature means that sealing to Crofer-22 APU with these compositions would be difficult. It is also interesting to observe that the greatest shrinkage is observed for sample BCABS-2P and that the reduction in shrinkage is marked between BCABS-3P and 4P. This would indicate that at and beyond $3 \mathrm{~mol} \% \mathrm{P}_{2} \mathrm{O}_{5}$ incorporation, crystalline phosphate phase separation occurs, as was also observed in borosilicate and alumino borosilicate glasses, which seems to hinder further shrinkage of the samples. This observation is supported by X-Ray diffractograms (Fig. 10) and ${ }^{31} \mathrm{P}$ MAS NMR (Fig. 11) that reveal the formation of $\mathrm{Ba}_{3}\left(\mathrm{PO}_{4}\right)$ phase in glass-ceramics containing more than $2 \mathrm{~mol} \% \mathrm{P}_{2} \mathrm{O}_{5}$.

Since the incorporation of $\mathrm{P}_{2} \mathrm{O}_{5}$ removes alkaline earth cations according to reaction (1), the effective glass composition shifts towards the hexacelsian forming region of the barium aluminum silicate phase diagram. As a result, the major phase formed changes from $\mathrm{BaSiO}_{3}$ to a mixture of hexacelsian, calcium/ barium phosphates and barium aluminum oxide. MASNMR spectra of the glass-ceramics are in accordance with the phase emergence observed by XRD. However, there is no crystalline resonance on the ${ }^{29} \mathrm{Si}$ spectra of the glass-ceramics (Fig. 12a) corresponding to hexacelsian. This is attributed to the presence of significant Al-Si disorder in hexacelsian similar to other feldspar family minerals [42]. Interestingly, while ${ }^{29} \mathrm{Si}$ NMR spectra do not show any narrow resonance, the ${ }^{27} \mathrm{Al}$ spectra (Fig. 12b) show narrowing attributed to crystallization of hexacelsian and mainly barium aluminum oxide that contain $\mathrm{Al}$ in tetrahedral coordination. This could perhaps be due to a greater fraction of the total $\mathrm{Al}$ in the glass being involved in the crystalline phases as compared to Si.

The crystallization of phosphate containing phases observed in XRD allows BCABS-4P and 5P glassceramics to have high TEC despite the crystallization of hexacelsian, which a lower than desired TEC $\left(8 \times 10^{-6} /{ }^{\circ} \mathrm{C}\right)$. The large fraction of aluminium-rich crystalline phases in these glass-ceramics means that the residual glass is enriched in silica and these consequently have higher $T_{\mathrm{g}}$. Since thermal stresses 


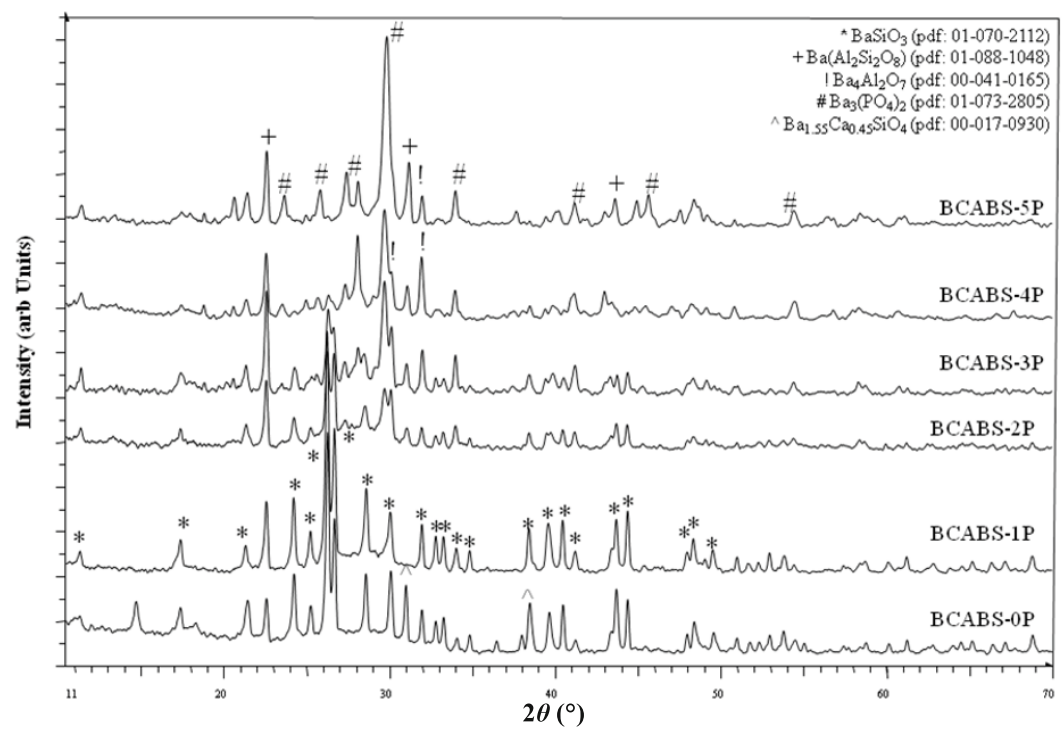

Fig. 10 XRD patterns recorded at room temperature for BCABS-0P to $5 \mathrm{P}$ glass-ceramics formed by heat treating BCABS glasses according to the schedule described in the text. The phases formed are indicated in the diagram on the top right corner.

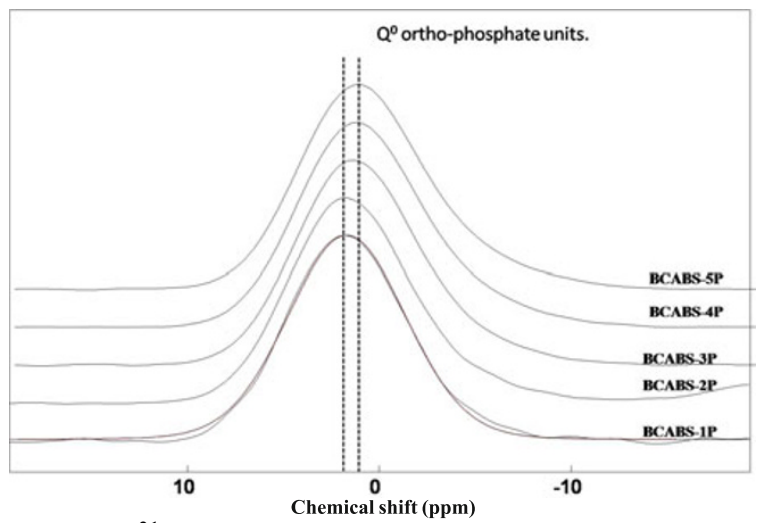

Fig. $11{ }^{31} \mathrm{P}$ MAS-NMR spectra of BCABS-0P to $5 \mathrm{P}$ glasses

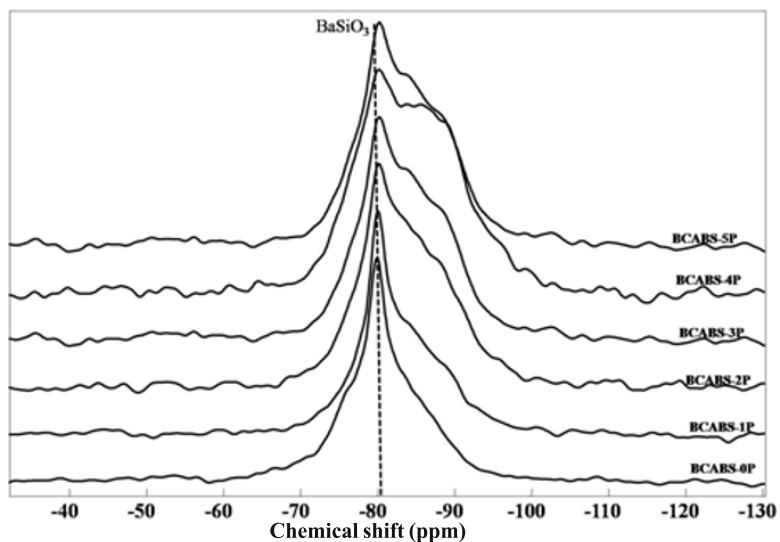

(a) develop below $T_{\mathrm{g}}$, this can render these materials vulnerable to cracking under thermal cycling. Similarly, BCABS glass-ceramics with low $\mathrm{P}_{2} \mathrm{O}_{5}$ content show crystallization of $\mathrm{BaSiO}_{3}$, and thus also display a reduction in $T_{\mathrm{g}}$ due to removal of $\mathrm{SiO}_{2}$ from the residual glassy phase.

Since the flow and sealing temperatures increase with $\mathrm{P}_{2} \mathrm{O}_{5}$, interface studies were carried out using BCABS-0P, 1P and 2P glasses, as these could be sealed to Crofer-22APU alloy below $1000{ }^{\circ} \mathrm{C}$. With increasing $\mathrm{P}_{2} \mathrm{O}_{5}$, dendrites of $\mathrm{BaSiO}_{3}$ (confirmed by WDX analysis) are more uniformly distributed in the bulk of the glass-ceramic, which gives superior properties compared to surface crystallization. However, as

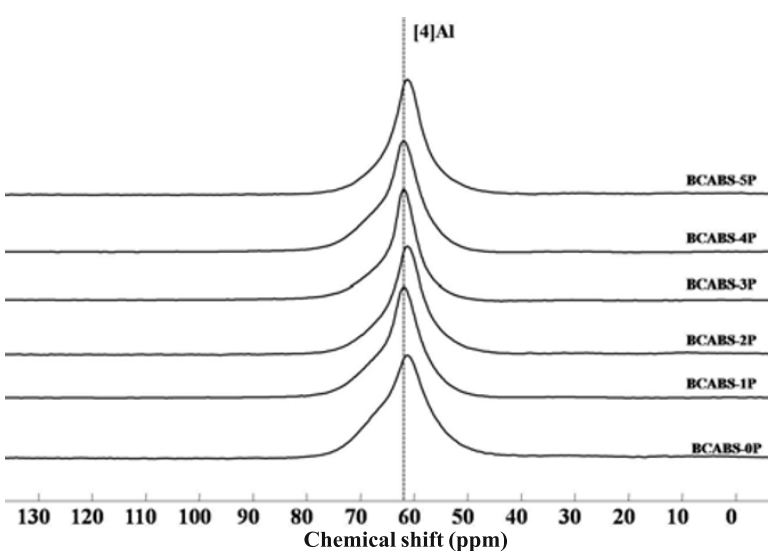

(b)

Fig. 12 (a) 29Si MAS-NMR spectra of BCABS-0P to 5P glass-ceramics. In the glass- ceramics, the crystalline resonance at c.a. $-80 \mathrm{ppm}$ is attributed to $\mathrm{BaSiO} 3$. $\mathrm{Ba}(\mathrm{Al} 2 \mathrm{Si} 2 \mathrm{O} 8)$ does not present a narrow crystalline resonance due to Al-Si disorder. (b) 27Al MAS-NMR spectra of BCABS-0P to 5P glass-ceramics exhibiting Al in tetrahedral coordination although the resonances are narrower indicating the onset of crystalline ordering. 
discussed previously, it also interferes with densification upon sintering.

Although the quantity of $\mathrm{P}_{2} \mathrm{O}_{5}$ in the samples is small, making detection difficult, comparing the $\mathrm{P}$ map of glass-ceramics remote from and proximal to the interface seems to indicate a depletion of $\mathrm{P}_{2} \mathrm{O}_{5}$ near the interface as shown in Fig. 13. This figure represents the WDX images of BCABS-1P but similar behaviour is observed in case of BCABS-2P. Based upon the data, we can tentatively suggest that the $\mathrm{P}_{2} \mathrm{O}_{5}$ at the interface reacts with the $\mathrm{Cr}$ according to the following reactions [4]:

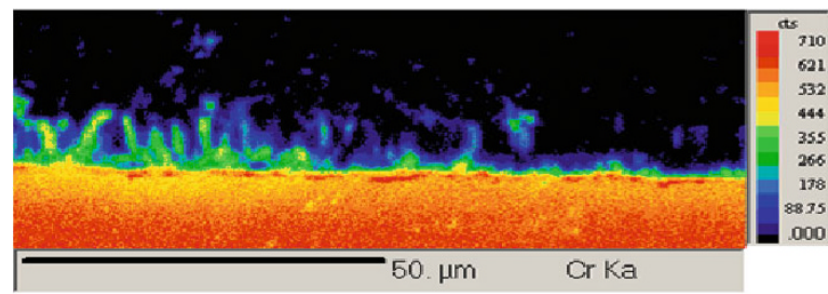

(a)

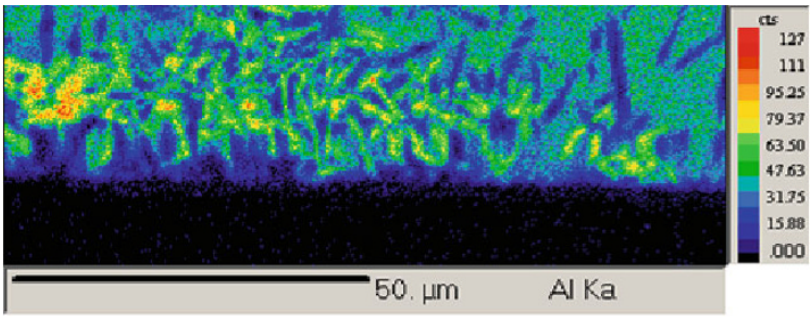

(c)

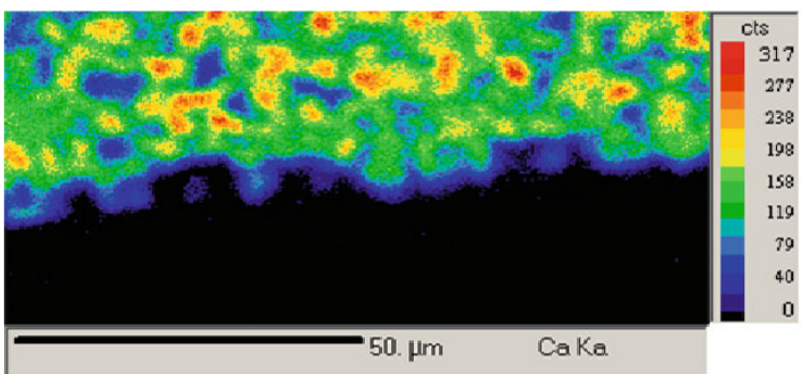

(e)

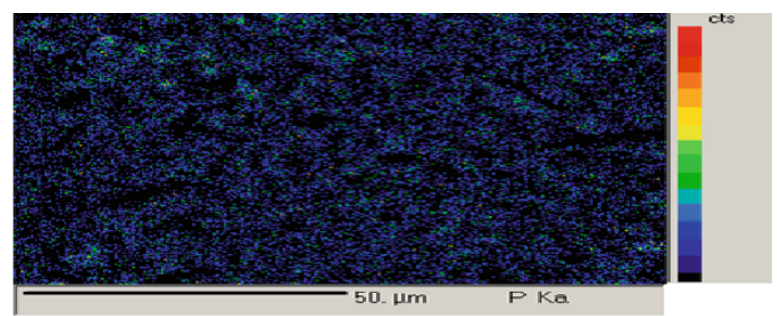

(g)

$$
\begin{gathered}
\mathrm{Cr}^{-}+3 / 10 \mathrm{P}_{2} \mathrm{O}_{5} \rightarrow 1 / 2 \mathrm{Cr}_{2} \mathrm{O}_{3}+3 / 5 \mathrm{P} \uparrow \\
\mathrm{Cr}^{-}+1 / 5 \mathrm{P}_{2} \mathrm{O}_{5} \rightarrow \mathrm{CrO}+2 / 5 \mathrm{P} \uparrow
\end{gathered}
$$

On the basis of the $\mathrm{Cr}$ and $\mathrm{P}$ maps, it is not possible to conclude whether Reaction (3) or (4) is predominant. However, both reactions result in the formation of $\mathrm{P}$ vapors that must leave pores in the glass at the interface. We were unable to observe any such pores at the interface in the BSE images (Fig. 14h for example) [39] and postulate that the pores might be closed near the sealing temperature owing to the fluidity of the glass at elevated temperatures. While further studies are necessary to determine the redox reactions

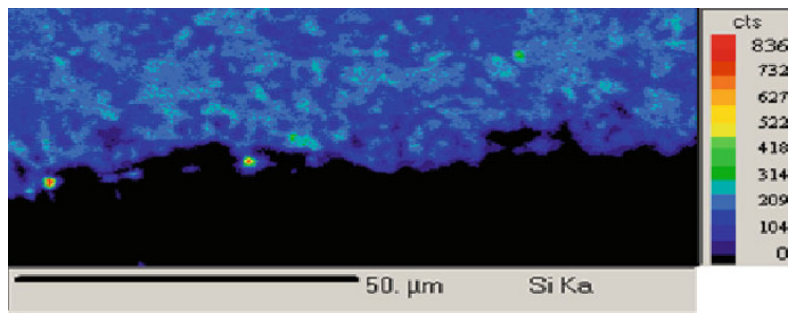

(b)

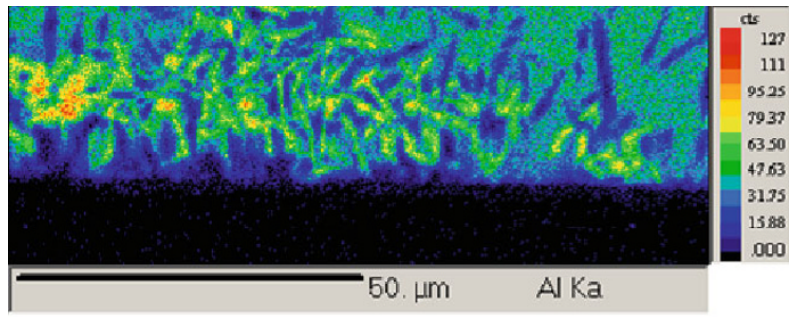

(d)

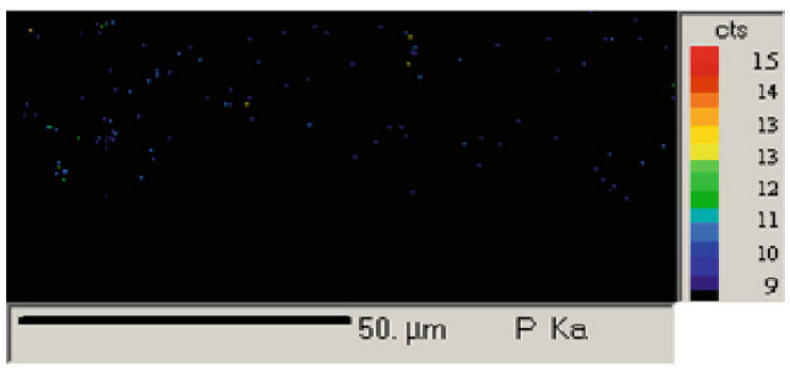

(f)

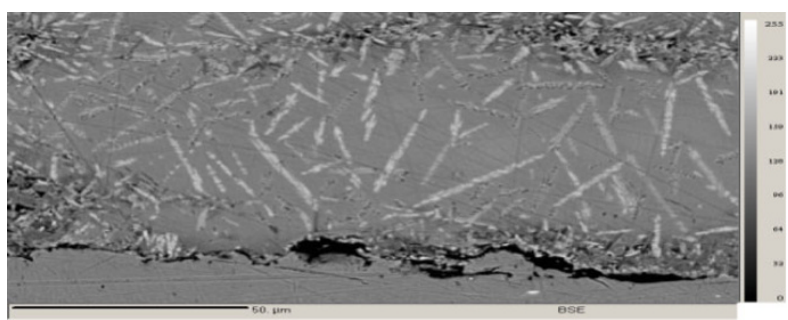

(h)

Fig. 13 Characteristic X-ray images of the BCABS-1P to Crofer 22 APU interface showing the distribution of (a) $\mathrm{Cr}$, (b) $\mathrm{Si}$, (c) Al, (d) Ba, (e) $\mathrm{Ca}$, (f) P proximal to the interface, (g) P in the bulk of the glass-ceramic and (h) showing the microstructure at the interface with visible $\mathrm{BaSiO} 3$ dendrites 


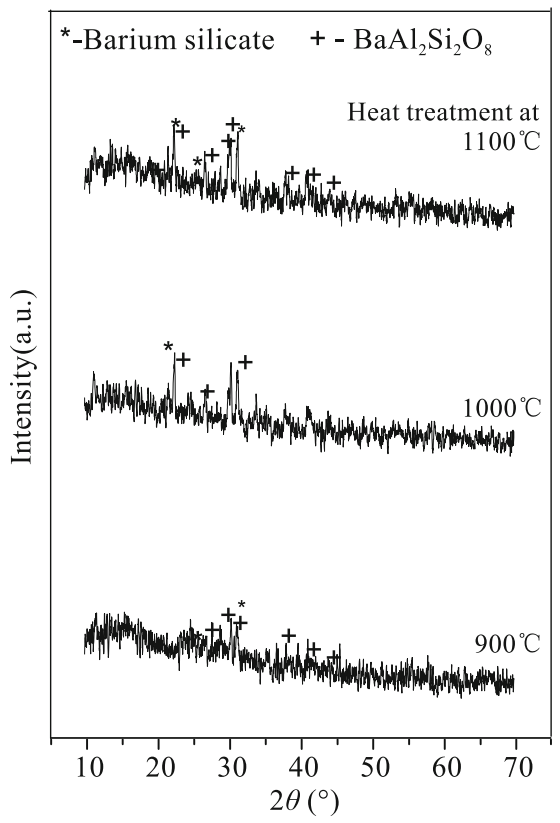

(a)

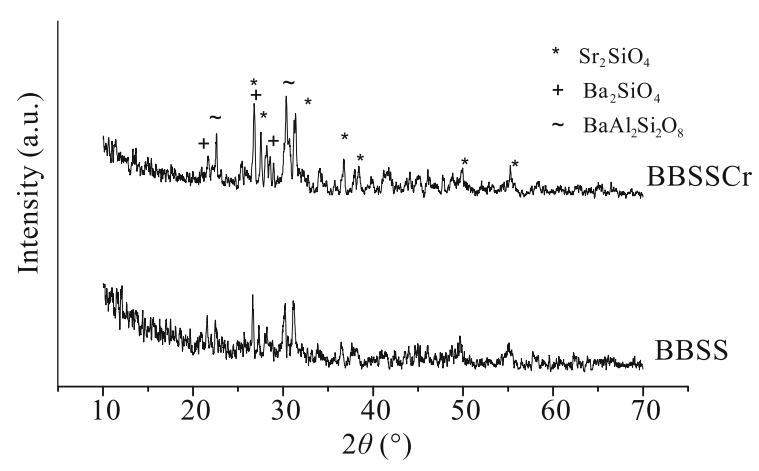

(b)

Fig. 14 (a) XRD plots of BSS after different heat treatment and (b) BBSS and BBSSCr after heat treatment $800{ }^{\circ} \mathrm{C}$ for $6 \mathrm{~h}$

occurring at the glass-ceramic-to-metal interface, it is clear that either Reaction (3) or (4) would yield an interface saturated with metal ions. Since glass-tometal bonding is enhanced by an interface saturated in metal ion, incorporation of $\mathrm{P}_{2} \mathrm{O}_{5}$ may improve adhesion [4].

It is also observed that despite $\mathrm{P}_{2} \mathrm{O}_{5}$ incorporation, diffusion of $\mathrm{Cr}^{3+}$ ions persists at the interface implying that $\mathrm{BaCrO}_{4}$ formation continues to be an issue and this can be a limitation for applicability [43]. Incorporation of $\mathrm{P}_{2} \mathrm{O}_{5}$ into barium calcium aluminum borosilicate glass removes modifier cations from the silicate network, which leads an increased network polymerization. The consequences are the higher sintering temperatures and an increased crystallization tendency. The latter, allied with high sealing temperatures means that $\mathrm{BCABS}$ glass doping should be limited to up to $2 \mathrm{~mol} \% \mathrm{P}_{2} \mathrm{O}_{5}$. Above $2 \mathrm{~mol} \%$ phase emergence changes from silicates to aluminosilicates and phosphates, which compromise the thermo-physical properties of the glass-ceramics. This implies that doping should be limited to $2 \mathrm{~mol} \%$ $\mathrm{P}_{2} \mathrm{O}_{5}$ so that the major phase formed remains $\mathrm{BaSiO}_{3}$ and the hexacelsian formation is minimized. However, at $2 \mathrm{~mol} \% \mathrm{P}_{2} \mathrm{O}_{5}$, incomplete sintering was evident in HSM measurements, due to rapid crystallization. Interface observations of glass-ceramics with Crofer alloy did not show any detrimental effect of $\mathrm{P}_{2} \mathrm{O}_{5}$, and bonding may even be enhanced by increased $\mathrm{Cr}$ diffusion. Therefore, we conclude that incorporation of $1 \mathrm{~mol} \% \mathrm{P}_{2} \mathrm{O}_{5}$ improves the sealing characteristics of BCABS glass-ceramics [39].

\section{Sealants based on barium/strontiun zinc silicate (B/SZS) glass-ceramics}

In order to evaluate the effect of $\mathrm{La}_{2} \mathrm{O}_{3}$ and $\mathrm{Cr}_{2} \mathrm{O}_{3}$ on glass properties and sealing behaviour, $\mathrm{SrO} / \mathrm{BaO}$ based silicate glasses with these additives were prepared. Nominal compositions (in mole \%) of the glass samples are listed in Table 4. The attendant changes in thermo-physical properties of the glasses are collated in Table 5. The $T_{\mathrm{g}}$ and TEC values reported in Table 5 are determined from TMA plots. The data presented in Table 5 indicates a reduction in $T_{\mathrm{g}}$ and an augmentation of TEC with incorporation of $\mathrm{B}_{2} \mathrm{O}_{3}$. The TEC values of the glass samples are found to be in the acceptable range for SOFC sealing.

Table 4 Nominal composition of glasses prepared with various additives

\begin{tabular}{cccccccc}
\hline Sample & $\mathrm{SiO}_{2}$ & $\mathrm{SrO}$ & $\mathrm{BaO}$ & $\mathrm{La}_{2} \mathrm{O}_{3}$ & $\mathrm{Al}_{2} \mathrm{O}_{3}$ & $\mathrm{~B}_{2} \mathrm{O}_{3}$ & $\mathrm{Cr}_{2} \mathrm{O}_{3}$ \\
\hline BSS & 38 & 20 & 30 & 0 & 10 & 0 & 2 \\
BBSS & 30 & 20 & 30 & 05 & 05 & 10 & 0 \\
BBSSCr & 30 & 20 & 30 & 05 & 05 & 8 & 2 \\
\hline
\end{tabular}


Table 5 Thermo-physical properties of parent glasses

\begin{tabular}{lcc}
\hline Sample & TEC $( \pm 5 \%)\left(10^{\left.-6{ }^{\circ} \mathrm{C}^{-1}\right)}\right.$ & $T_{\mathrm{g}} \pm 2\left({ }^{\circ} \mathrm{C}\right)$ \\
\hline BSS & 10.0 & 670 \\
BBSS & 11.4 & 650 \\
BBSSCr & 12.0 & 652 \\
\hline
\end{tabular}

In glass and glass-ceramics, the thermo-physical properties are strongly dependent upon the composition [44,45]. In glasses, $\mathrm{SiO}_{2}$ acts as network forming oxide [45]. Decreasing the silica content and increasing $\mathrm{B}_{2} \mathrm{O}_{3}$ reduces the rigidity of the glass network. Further, addition of $\mathrm{Cr}_{2} \mathrm{O}_{3}$ also contributes to decreasing network polymerization. Thus, the addition of $\mathrm{B}_{2} \mathrm{O}_{3}$ and $\mathrm{Cr}_{2} \mathrm{O}_{3}$ lead to an increase in the TEC of glasses, while $T_{\mathrm{g}}$ decreases.

XRD patterns of different glass samples after controlled heat treatment at different temperature are depicted in Fig. 14a. The BSS glass after heat treatment shows the formation of $\mathrm{BaSiO}_{3}$ and $\mathrm{BaAl}_{2} \mathrm{Si}_{2} \mathrm{O}_{8}$. However, the intensity of crystalline reflections is low implying the samples are not well crystallized. The others samples BBSS and BBSSCr showed comparatively good crystallization behaviour. XRD patterns of these glasses after controlled heat treatment at $800{ }^{\circ} \mathrm{C}$ (Fig. 14b) reveal the formation of $\mathrm{Ba}_{2} \mathrm{SiO}_{4}, \mathrm{BaAl}_{2} \mathrm{Si}_{2} \mathrm{O}_{8}$ and $\mathrm{Sr}_{2} \mathrm{SiO}_{4}$.

The glass transition temperature of glass corresponds to viscosity of $10^{11.3} \mathrm{~Pa} \cdot \mathrm{s}$. Viscosity of the glass decreases with increasing temperature and significant wetting of metal is possible at higher temperature, where viscosity decreases to around $10^{7}$ $10^{4}$ poise. Sealing of BSS glass with Crofer 22 APU alloy was possible at $1150-1200{ }^{\circ} \mathrm{C}$. However, for others composition satisfactory sealing is possible near $1000{ }^{\circ} \mathrm{C}$. The seals prepared with BBSS exhibits good bonding with metallic interconnect even after holding at $800{ }^{\circ} \mathrm{C}$ up to $500 \mathrm{~h}$. Leak testing of seals were carried out and were found to withstand a vacuum of $10^{-6}$ Torr at room temperature.

\section{Crystallization kinetics of SZS glasses}

While $\mathrm{BaO}$ is a commonly used modifier in SOFC glasses, it leads to $\mathrm{BaCrO}_{4}$ formation, which cannot be completely avoided owing to the highly negative Gibb's free energy of this phase at elevated temperatures, particularly in oxidizing environments [43]. Therefore, we investigate $\mathrm{SrO}$ containing silicates as potential sealant materials. It has been shown that incorporation of $\mathrm{ZnO}$ into strontium silicate glasses greatly mitigates the formation of $\mathrm{SrCrO}_{4}$. Prolonged use of the silicate glass at elevated SOFC temperatures will lead to crystallization and conversion of the glass into a glass-ceramic. Therefore, it is of great importance to understand the crystallization kinetics of the $\mathrm{SrO}-\mathrm{ZnO}-\mathrm{SiO}_{2}$ (SZS) glasses. Toward this, we performed DTA experiments on an SZS glass of composition (wt. \%) $51 \mathrm{SrO}-9 \mathrm{ZnO}-40 \mathrm{SiO}_{2}$ at heating rates ranging from $5-20 \mathrm{~K} \cdot \mathrm{min}^{-1}$ in an atmosphere of flowing Ar. We have discussed the details of the DTA measurements elsewhere [46]. The crystallization kinetics has been investigated using both the Kissinger [47] and Matusita-Sakka [48] methods. The latter method is needed because in the present glasses, there is a strong likelihood of nucleation occurring during crystal growth [48-50]. This situation will lead to an underestimation of the activation energy for crystallization derived from the Kissinger method, which assumes growth from a fixed number of nuclei [47-50]. The DTA curve on the SZS glass is presented in Fig. 15. It shows an endothermic event corresponding to $T_{\mathrm{g}}$ at nearly $700{ }^{\circ} \mathrm{C}$, while the a crystallization exotherm is evident at $\sim 900{ }^{\circ} \mathrm{C}$. The exotherm was deconvoluted into two Gaussian peaks at $877{ }^{\circ} \mathrm{C}$ and $917^{\circ} \mathrm{C}$ (Fig. 15). The position of these exotherms as a function of the heating rate is collated in Table 6 . The activation energy was evaluated by the Kissinger equation and Matusita Sakka expression, the details of which we have discussed elsewhere [46].

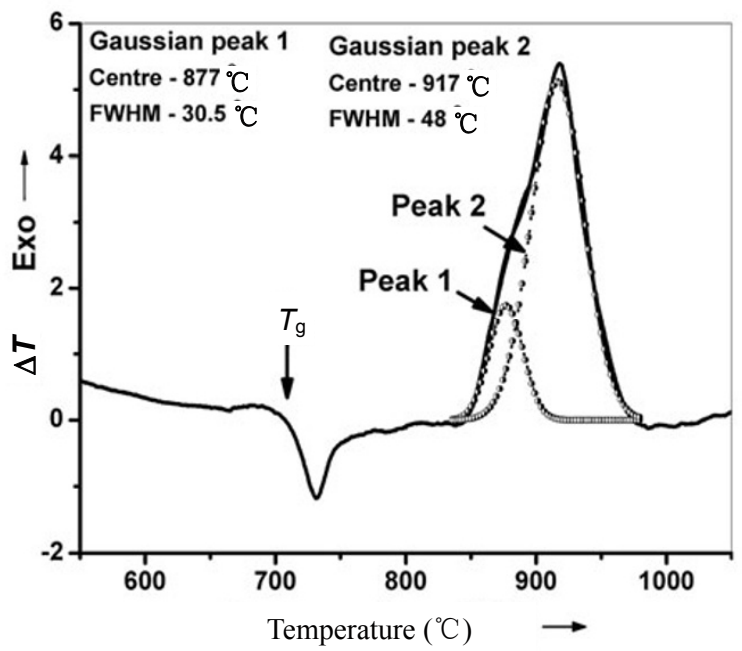

Fig. 15 DTA curve of the SZS glass at a heating rate of $\alpha=10{ }^{\circ} \mathrm{C} / \mathrm{min}$ 
Table 6 Peak Temperatures of exotherms at different heating rates for the SZS glass

\begin{tabular}{ccc}
\hline Heating rate $(\alpha)\left({ }^{\circ} \mathrm{C} / \mathrm{min}\right)$ & $T_{\mathrm{p} 1}\left({ }^{\circ} \mathrm{C}\right)$ & $T_{\mathrm{p} 2}\left({ }^{\circ} \mathrm{C}\right)$ \\
\hline 5 & 860 & 896 \\
10 & 877 & 917 \\
15 & 889 & 929 \\
20 & 895 & 942 \\
\hline
\end{tabular}

The activation energy and crystallization growth parameters for the SZS glass are presented in Table 7. The values $n$ and $m$ presented in Table 7 indicate bulk crystallization with varying number of nuclei and diffusion controlled bulk crystallization $[49,50]$. The bulk crystallization is expected to proceed by 3 and 2 dimensional growth in case of peaks 1 and 2 respectively [48-50]. It is interesting to observe that if the activation energies obtained from the Kissinger method are corrected according to $E_{a} \approx(n / m) E_{a k}$ then there exists reasonable agreement between the activation energies measured by the Kissinger and Matusita-Sakka methods. Further, the activation energy obtained is quite high (Table 7) indicating thermally activated crystallization kinetics. The high crystalli- zation temperature coupled with the diffusion dominated crystallization behaviour makes controlling the crystallization process more difficult.

Since two exotherms were evident in the DTA curve, crystallization of at least two phases is expected. Glasses were heat treated at different temperatures as shown in Table 8. Also presented in Table 8 are the phases realized upon heat treatment. The corresponding X-ray diffractograms are presented in Fig. 16. The samples heat treated at $720{ }^{\circ} \mathrm{C}$ for $1 \mathrm{~h}$, $750{ }^{\circ} \mathrm{C}$ for $5 \mathrm{~h}$ and $820{ }^{\circ} \mathrm{C}$ for $1 \mathrm{~h}$ are amorphous. In the sample heat treated at $820{ }^{\circ} \mathrm{C}$ for $2 \mathrm{~h}, \mathrm{ZnSiO}_{3}, \mathrm{SiO}_{2}$, $\mathrm{Sr}_{2} \mathrm{ZnSiO}_{2}$ and $\mathrm{Sr}_{3} \mathrm{Si}_{3} \mathrm{O}_{9}$ are evident in the X-ray diffractograms (Fig. 17). In the glass sample heat treated at $850{ }^{\circ} \mathrm{C}$ for $2 \mathrm{~h}$, the fraction of $\mathrm{ZnSiO}_{3}$ and $\mathrm{SiO}_{2}$ decreases in comparison to $\mathrm{Sr}_{2} \mathrm{ZnSiO}_{2}$ and $\mathrm{Sr}_{3} \mathrm{Si}_{3} \mathrm{O}_{9}$. We postulate that $\mathrm{ZnSiO}_{3}$ and $\mathrm{SiO}_{2}$ are replaced by $\mathrm{Sr}_{2} \mathrm{ZnSiO}_{2}$ and $\mathrm{Sr}_{3} \mathrm{Si}_{3} \mathrm{O}_{9}$ as the major phase according to the following reactions [46]:

$$
\mathrm{SiO}_{2} \text { (hexagonal) }+\mathrm{SrO} \text { (glass) } \rightarrow
$$$$
\mathrm{SrSiO}_{3} \text { (monoclinic) } / \mathrm{Sr}_{3} \mathrm{Si}_{3} \mathrm{O}_{9}
$$

$\mathrm{ZnSiO}_{3}$ (orthorhombic) $+2 \mathrm{SrO}$ (glass) $+\mathrm{SiO}_{2}$ (glass) $\rightarrow$

$$
\mathrm{Sr}_{2} \mathrm{ZnSi}_{2} \mathrm{O}_{7} \text { (tetragonal) }
$$

Table 7 Activation energy and growth morphology parameters for crystallization of the SZS glass

\begin{tabular}{ccccccc}
\hline Sample & Peak & Average $n$ (Ozawa) & $m$ (Matusita) & $\begin{array}{c}E_{\text {ak }}(\mathrm{kJ} / \mathrm{mol}) \\
(\text { Kissinger })\end{array}$ & $\begin{array}{c}E_{\mathrm{a}}(\mathrm{kJ} / \mathrm{mol}) \\
(\text { Matusita) }\end{array}$ & $\begin{array}{c}(\mathrm{n} / \mathrm{m}) \\
E_{\text {ak }}(\mathrm{kJ} / \mathrm{mol})\end{array}$ \\
\hline \multirow{2}{*}{ SZS glass $(75-200 \mu \mathrm{m}$ particle size) } & 1 & $2.67(\sim 2.5)$ & 1.5 & 409 & 700 & 681 \\
& 2 & $1.95(\sim 2)$ & 1.0 & 342 & 704 & 684 \\
\hline
\end{tabular}

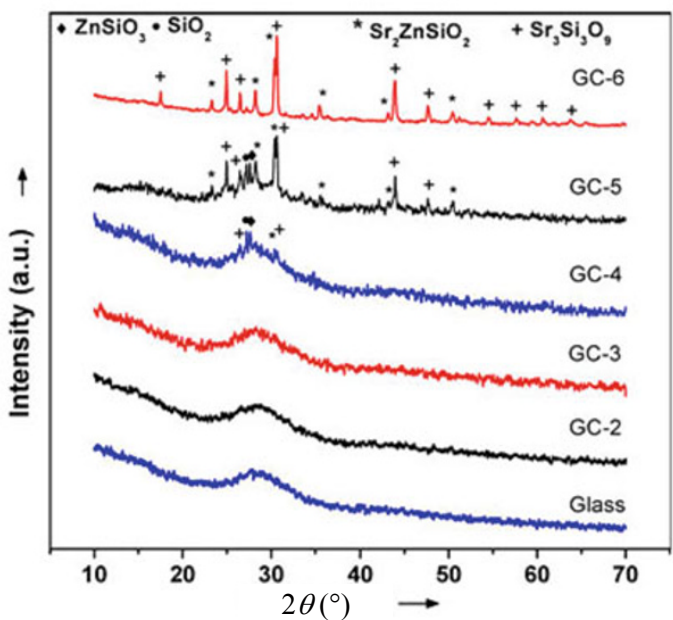

Fig. 16 Powder X-ray diffractograms of the SZS glass and glass-ceramics, produced by heat treatment of glass at different temperatures and for time durations

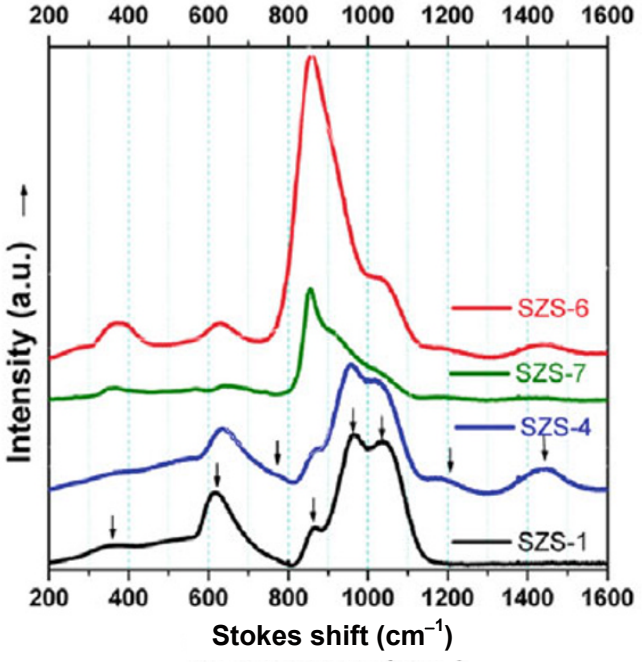

Fig. 17 Room temperature Raman spectra of investigated SZS glasses 
Table 8 Heat-treatment schedules of the SZS glass-ceramics

\begin{tabular}{cccll}
\hline Nomenclature & $\begin{array}{c}\text { Heating } \\
\text { temperature }\left({ }^{\circ} \mathrm{C}\right)\end{array}$ & $\begin{array}{c}\text { Dwell } \\
\text { time }(\mathrm{h})\end{array}$ & \multicolumn{1}{c}{ Crystalline phases } \\
\hline $\mathrm{GC}-1$ & 750 & 1 & Amorphous \\
$\mathrm{GC}-2$ & 750 & 5 & Amorphous \\
$\mathrm{GC}-3$ & 820 & 1 & Amorphous \\
$\mathrm{GC}-4$ & 820 & 2 & $\mathrm{SiO}_{2}, \mathrm{ZnSiO}_{3}, \mathrm{Sr}_{3} \mathrm{Si}_{3} \mathrm{O}_{9}, \mathrm{Sr}_{2} \mathrm{ZnSi}_{2} \mathrm{O}_{7}$ \\
$\mathrm{GC}-5$ & 850 & 2 & $\mathrm{Mainly} \mathrm{Sr}_{3} \mathrm{Si}_{3} \mathrm{O}_{9}, \mathrm{Sr}_{2} \mathrm{ZnSi}_{2} \mathrm{O}_{7}$ and minor quantity of $\mathrm{SiO}_{2}, \mathrm{ZnSiO}_{3}$ \\
GC-6 & 925 & 2 & $\mathrm{Sr}_{3} \mathrm{Si}_{3} \mathrm{O}_{9}, \mathrm{Sr}_{2} \mathrm{ZnSi}_{2} \mathrm{O}_{7}$ \\
\hline
\end{tabular}

In the sample heat treated at $925{ }^{\circ} \mathrm{C}, \mathrm{Sr}_{2} \mathrm{ZnSiO}_{2}$ and $\mathrm{Sr}_{3} \mathrm{Si}_{3} \mathrm{O}_{9}$ are the only phases detected on the X-ray diffractogram (Fig. 16). With increasing heat treatment temperature, the crystalline peaks in the X-ray diffractograms become more pronounced and the braod background attributed to the glassy phase decreases, indicating increasing crystallinity of the sample. Further, assuming all the $\mathrm{ZnO}$ in the glass participates in the formation of $\mathrm{Sr}_{2} \mathrm{ZnSiO}_{2}$ and all the $\mathrm{SrO}$ participates in the formation of $\mathrm{Sr}_{2} \mathrm{ZnSiO}_{2}$ and $\mathrm{Sr}_{3} \mathrm{Si}_{3} \mathrm{O}_{9}$, we can estimate that the glass can reach at most $\sim 87 \%$ crystallization. We can rule out further crystallization of $\mathrm{SiO}_{2}$ based on the absence of more than 2 exotherms in DTA. The diffractogram of the glass treated at $925^{\circ} \mathrm{C}$ shows high crystallinity and it appears that it has crystallized to near the maximum extent possible. However, we are pursuing long term heat treatment studies to verify that there is no further crystallization.

The SEM micrographs of the SZS glasses after being heat treated according to various schedules are presented in Fig. 18. The as prepared glass is completely uniform, testifying the homogeneity of the prepared glass (Fig. 18a). In the sample heat treated at $750{ }^{\circ} \mathrm{C}$ for $5 \mathrm{~h}$, a vermicular phase separated structure is evident. It is likely that the SZS glass undergoes a glass in glass phase separation by the spinodal decomposition mechanism on the length scale of 50 $-500 \mathrm{~nm}$, leading to the characteristic connected morphology (Fig. 18b) [51]. Upon heat treating at $820{ }^{\circ} \mathrm{C}$, the phase separation, driven by the higher temperature becomes more evident and the boundaries between the phase separated regions become more distinct, growing to a length scale of 1-2 $\mu \mathrm{m}$ (Fig. 18c). In the sample heat treated at $850{ }^{\circ} \mathrm{C}$, which is close to the crystallization onset temperature (Fig. 15), the phase separated regions begin crystallizing and some granular/prismatic crystals about $2-4 \mu \mathrm{m}$ in size are evident (Fig. 18d). These crystals are more numerous in the sample heat treated at $925{ }^{\circ} \mathrm{C}$ and the interconnected structure is very clearly evident for this sample (Fig. 18e). Also evident is the high crystallinity of the sample, confirming the X-ray diffractograms. The highly interconnected nature of the two phases clearly indicates the spinodal decomposition and phase separation occurs in the SZS glasses into regions rich in $\mathrm{ZnO}$ and regions rich in $\mathrm{SiO}_{2}$ [51]. The $\mathrm{ZnO}$ rich regions crystallize to yield $\mathrm{Sr}_{2} \mathrm{ZnSi}_{2} \mathrm{O}_{7}$, while $\mathrm{Sr}_{3} \mathrm{Si}_{3} \mathrm{O}_{9}$ forms in the $\mathrm{SiO}_{2}$ rich regions. Phase separation tendencies in binary $\mathrm{SrO}_{-} \mathrm{SiO}_{2}[52]$ and $\mathrm{ZnO}-\mathrm{SiO}_{2}$ [53] systems are well known and it is therefore not really surprising that such behaviour persists in the ternary SZS glasses.

In the SZS glasses, the phase separation behaviour may lead to problems with degradation resistance particularly in the $\mathrm{ZnO}$ rich regions, which may persist for a longer time if the SOFC is operated at around $750-800{ }^{\circ} \mathrm{C}$. However, the rapid crystallization of SZS glasses to yield phases with acceptable TEC and stability is a major advantage. Further studies involving long durations of holding at elevated temperature are presently underway.

\section{Effect of various additives in the SZS system}

The glasses belonging to the SZS system have not been explored very commonly for sealing for SOFCs. In the previous section we discussed how the phase emergence behavior and crystallization kinetics of SZS glasses are promising for SOFC sealing applications. In this section, we discuss the effect of various additives such as $\mathrm{B}_{2} \mathrm{O}_{3}, \mathrm{Al}_{2} \mathrm{O}_{3}, \mathrm{~V}_{2} \mathrm{O}_{5}$, and $\mathrm{Cr}_{2} \mathrm{O}_{3}$ in the SZS system [54]. The changes in the glass structure resulting from the composition modification were observed using Raman spectroscopy. The changes in phase emergence were studied using XRD and sealing studies with promising compositions was carried out to ensure that the SZS glasses show adequate bonding 

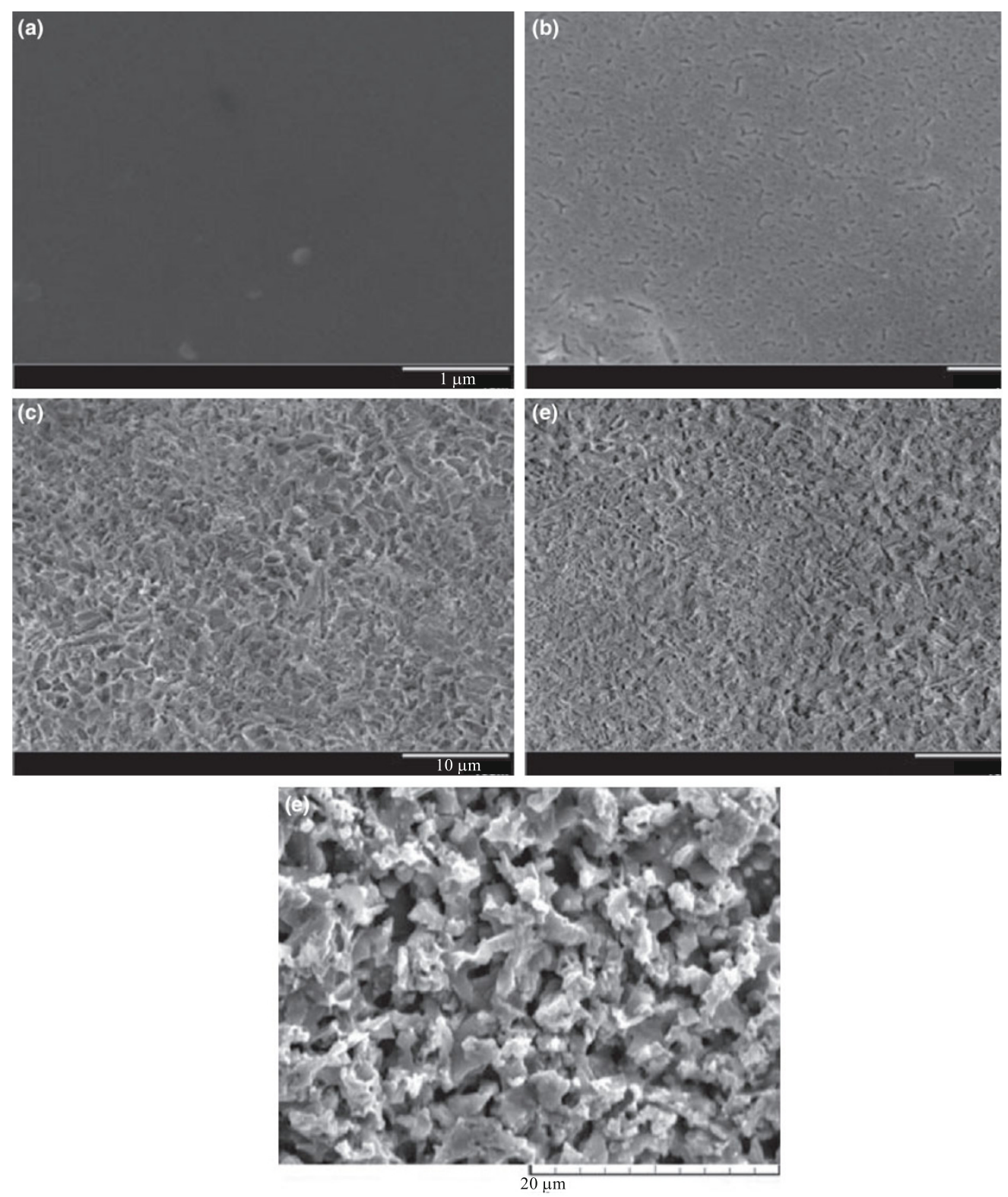

Fig. 18 SEM micrographs of the SZS glass and glass-ceramics (a) as-prepared glass, (b) glass-ceramic GC-2, crystallized at $750{ }^{\circ} \mathrm{C}$ for $5 \mathrm{~h}$, (c) glass-ceramic GC-4, crystallized at $820{ }^{\circ} \mathrm{C}$ for $2 \mathrm{~h}$, (d) glass-ceramic GC-5, crystallized at $850{ }^{\circ} \mathrm{C}$ for $2 \mathrm{~h}$, and (e) glass-ceramic GC-6, crystallized at $925{ }^{\circ} \mathrm{C}$ for $2 \mathrm{~h}$

characteristics with other SOFC components such as Crofer-22 APU and YSZ.

The compositions of the SZS glasses with various additives are presented in Table 9. Additives were added to modify the properties of the melt; $\mathrm{Al}_{2} \mathrm{O}_{3}$ for retarding crystallization, $\mathrm{B}_{2} \mathrm{O}_{3}$ for reducing sealing temperature and controlling viscosity. $\mathrm{V}_{2} \mathrm{O}_{5}$ and $\mathrm{Cr}_{2} \mathrm{O}_{3}$ were added to reduce surface tension of the glass $/ \mathrm{melt}$, which also act as nucleating agents in different glass compositions [39]. The details of glass preparation are discussed in the literature [54]. Various thermo-physical properties of glasses prepared are listed in Table 10.

Table 9 Chemical compositions (in wt. \%) of investigated SZS glasses

\begin{tabular}{|c|c|c|c|c|c|c|c|}
\hline $\begin{array}{c}\text { Glass } \\
\text { nomenclature }\end{array}$ & $\mathrm{SrO}$ & $\mathrm{ZnO}$ & $\mathrm{SiO}_{2}$ & $\mathrm{~B}_{2} \mathrm{O}_{3}$ & $\mathrm{~V}_{2} \mathrm{O}_{5}$ & $\mathrm{Al}_{2} \mathrm{O}_{3}$ & $\mathrm{Cr}_{2} \mathrm{O}_{3}$ \\
\hline SZS-1 & 51 & 9 & 40 & - & - & - & - \\
\hline SZS-4 & 51 & 9 & 30 & 10 & - & - & - \\
\hline SZS-6 & 49 & 9 & 30 & 8 & 4 & - & - \\
\hline SZS-7 & 51 & 9 & 30 & 5 & - & 3 & 2 \\
\hline
\end{tabular}


Table 10 Thermo-physical properties of investigated SZS glasses/glass-ceramics

\begin{tabular}{ccccccccc}
\hline Glass ID & $T_{\mathrm{g}}\left({ }^{\circ} \mathrm{C}\right)$ & $T_{\mathrm{ds}}\left({ }^{\circ} \mathrm{C}\right)$ & $\mathrm{TEC}\left(10^{-7} /{ }^{\circ} \mathrm{C}\right)$ & $T_{\mathrm{p} 1}\left({ }^{\circ} \mathrm{C}\right)$ & $T_{\mathrm{p} 2}\left({ }^{\circ} \mathrm{C}\right)$ & $\mathrm{MH}(\mathrm{GPa})$ & Density $\left(\mathrm{kg} / \mathrm{m}^{3}\right)$ & Major crystalline phases \\
\hline SZS-1 & 722 & 745 & 108 & 890 & 930 & 6.26 & 3680 & $\mathrm{Sr}_{2} \mathrm{ZnSi}_{2} \mathrm{O}_{7}, \mathrm{SrSiO}_{3}$ \\
SZS-4 & 643 & 676 & 105 & 820 & 860 & 7.13 & 3710 & $\mathrm{Sr}_{2} \mathrm{ZnSi}_{2} \mathrm{O}_{7}, \mathrm{SrSiO}_{3}$ \\
SZS-6 & 640 & 664 & 115 & 830 & - & 7.17 & 3660 & $\mathrm{Sr}_{2} \mathrm{ZnSi}_{2} \mathrm{O}_{7}$ \\
SZS-7 & 671 & 707 & 112 & 885 & - & 6.26 & 3780 & $\mathrm{SrSiO}_{3}$ \\
\hline
\end{tabular}

The prepared glasses were bubble free, transparent and colourless except those having $\mathrm{Cr}_{2} \mathrm{O}_{3}$ or $\mathrm{V}_{2} \mathrm{O}_{5}$ oxides. Glasses having $\mathrm{Cr}_{2} \mathrm{O}_{3}$ were dark greenish in colour due to $\mathrm{Cr}^{3+}$ ions and glasses having $\mathrm{V}_{2} \mathrm{O}_{5}$ were light greenish in colour due to $\mathrm{V}^{3+}$ ions. Characteristic broad hump in powder XRD pattern confirmed the amorphous nature of the prepared glasses. It is clear from Table 10 that investigated glasses have density in the range of $3.66-3.78 \mathrm{~g} / \mathrm{cc}$ and microhardness in the range of 6.26-7.17 GPa. Microhardness of all glasses was high, reflecting higher bond strength which increases penetration resistance during indentation [55]. Density of glass increases with addition of $\mathrm{B}_{2} \mathrm{O}_{3} / \mathrm{Al}_{2} \mathrm{O}_{3}$, since molecular weight of these oxides is higher as compared to molecular weight of $\mathrm{SiO}_{2}$. However, density remains almost same with the addition of $\mathrm{V}_{2} \mathrm{O}_{5}$ along with $\mathrm{B}_{2} \mathrm{O}_{3}$ as for glass SZS-6. This can be explained on the basis of two opposing effects. Higher molecular weight of the constituent oxides increases the density. Simultaneously, an open glass network consisting of $\mathrm{V}_{2} \mathrm{O}_{5}$ decreases density.

DTA plots of investigated glasses are shown in Fig. 19. Endothermic base line shift indicates the glass transition and exotherm indicates the crystallization. It is clear from Fig. 19 that for glass SZS-1 exotherm is

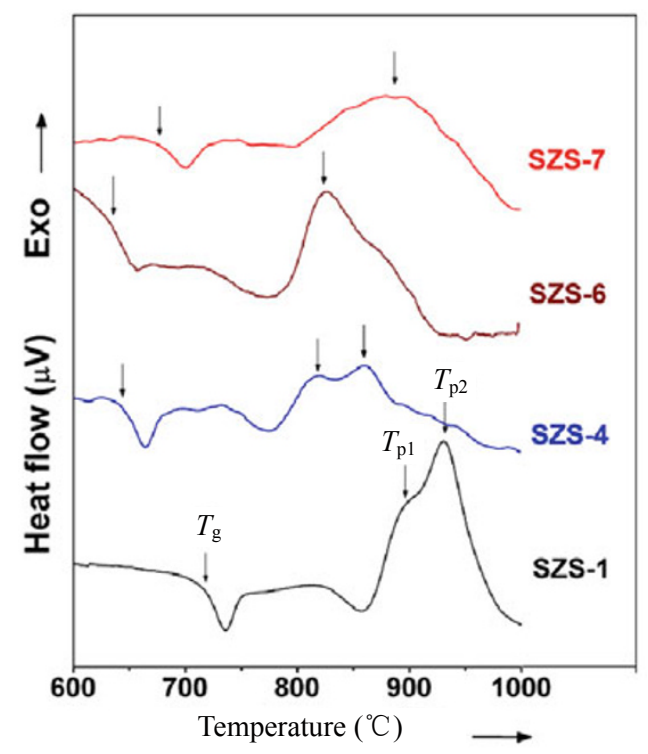

Fig. 19 DTA curve of investigated SZS glasses envelop of 2 overlapped peaks. Peak temperatures of these exotherms $T_{\mathrm{p} 1}$ and $T_{\mathrm{p} 2}$ are at around $890{ }^{\circ} \mathrm{C}$ and $930{ }^{\circ} \mathrm{C}$ respectively. Two exothermic peaks are corresponding to crystallization of two phases. Glass transition temperature and crystallization temperature reduces significantly with the addition of $\mathrm{B}_{2} \mathrm{O}_{3}$ for replacement of $\mathrm{SiO}_{2}$. Since $\mathrm{B}_{2} \mathrm{O}_{3}$ reduces the viscosity of the glass thereby increases the diffusion of ions which, in turn, causes crystallization of glass at lower temperature. For glass SZS-4 two exothermic peaks are more broad and separated. As a consequence, overall intensity of these 2 peaks also decreases. These observations indicate that $\mathrm{B}_{2} \mathrm{O}_{3}$ suppress the crystallization tendency [56,57]. For glass SZS-6 broad exotherm at around $830{ }^{\circ} \mathrm{C}$ is observed. This revealed that $\mathrm{V}_{2} \mathrm{O}_{5}$ is not an effective nucleating agent in the investigated composition. For glass SZS-7 exotherm peak becomes very broad and shifts towards higher temperature at $\sim 885{ }^{\circ} \mathrm{C}$. This shifting is due to the $\mathrm{Al}_{2} \mathrm{O}_{3}$ which retard the crystallization of the glass. Broadness of the exotherm indicates that $\mathrm{Cr}_{2} \mathrm{O}_{3}$ is not an effective nucleating agent in the investigated composition.

It is observed that with the addition of $\mathrm{B}_{2} \mathrm{O}_{3}, T_{\mathrm{g}}$ and $T_{\mathrm{ds}}$ reduces and TEC remains almost unchanged. Since $\mathrm{B}_{2} \mathrm{O}_{3}$ decrease the viscosity of the glass, it results in the reduction of $T_{\mathrm{g}}$ and $T_{\mathrm{ds}}$. For glass SZS-6 addition of $\mathrm{V}_{2} \mathrm{O}_{5}$ also contributes in the reduction of $T_{\mathrm{g}}$ since $\mathrm{V}_{2} \mathrm{O}_{5}$ reduces the surface tension of liquid. Addition of $\mathrm{V}_{2} \mathrm{O}_{5}$ along with $\mathrm{B}_{2} \mathrm{O}_{3}$ increases the TEC of the glass. TEC for the investigated glasses are in the range of 105$115 \times 10^{-7} /{ }^{\circ} \mathrm{C}\left(30{ }^{\circ} \mathrm{C}-T_{\mathrm{g}}\right)$, which is closely matched with the TEC of other SOFC components like interconnect, electrodes and electrolytes [58,59]. It is found that TEC of glasses after $2 \mathrm{~h}$ crystallization did not change much $\left(110-120 \times 10^{-7} /{ }^{\circ} \mathrm{C}\right)$. Softening temperature of all glass-ceramics is higher than $1000{ }^{\circ} \mathrm{C}$, which is advantageous for high temperature sealants. XRD spectra for different glass-ceramics are presented in Fig. 20. It is observed that for glass SZS-1 two crystalline phases $\mathrm{Sr}_{2} \mathrm{ZnSi}_{2} \mathrm{O}_{7}$ and $\mathrm{SrSiO}_{3}$ are formed, which correspond to 2 exothermic peaks in DTA data. 


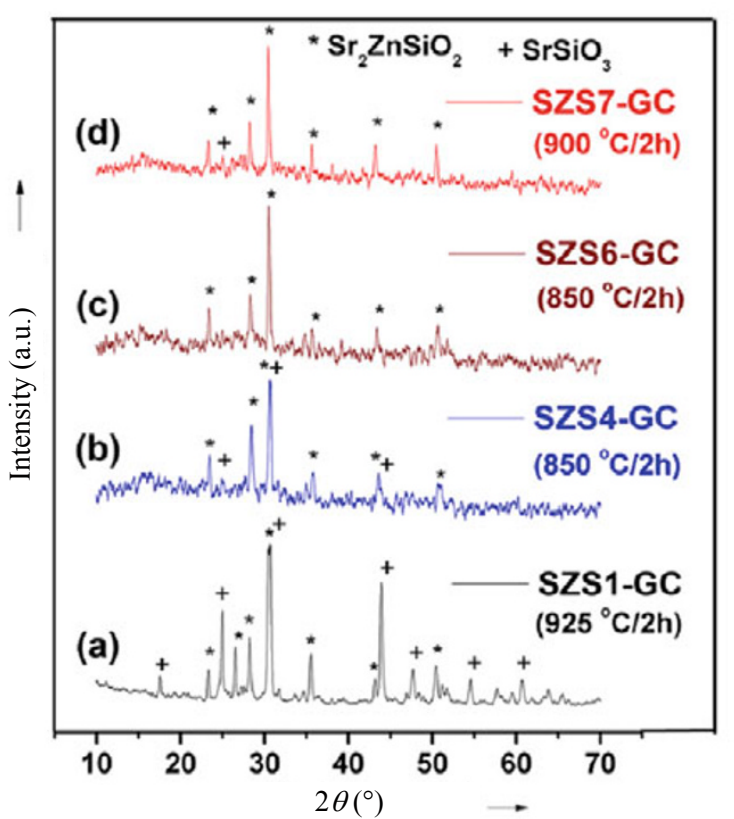

Fig. 20 Powder XRD spectra of SZS glassceramics (a) SZS1-GC crystallized at $925^{\circ} \mathrm{C}$ for $2 \mathrm{~h}$, (b) SZS4-GC crystallized at $850{ }^{\circ} \mathrm{C}$ for $2 \mathrm{~h}$, (c) SZS6-GC crystallized at $850{ }^{\circ} \mathrm{C}$ for $2 \mathrm{~h}$, (d) SZS7-GC crystallized at $900{ }^{\circ} \mathrm{C}$ for $2 \mathrm{~h}$

For glass SZS-4 also both the phases crystallize but intensity of peaks corresponding to $\mathrm{SrSiO}_{3}$ phase decreases which indicates the suppression of crystallization of this phase. For glass SZS-6 and SZS-7 mainly $\mathrm{Sr}_{2} \mathrm{ZnSi}_{2} \mathrm{O}_{7}$ phase crystallized. XRD results indicate that in the base composition (SZS-1) $\mathrm{Sr}_{2} \mathrm{ZnSi}_{2} \mathrm{O}_{7}$ and $\mathrm{SrSiO}_{3}$ phases crystallize and addition of additives suppress the crystallization of $\mathrm{SrSiO}_{3}$ phase, thus showing the presence of only $\mathrm{Sr}_{2} \mathrm{ZnSi}_{2} \mathrm{O}_{7}$ phase. It is reported that glass ceramics containing crystalline phases of theses silicate groups have high thermal expansion coefficient [58].

Raman spectra of investigated glasses revealed the information regarding the modification in structure of glasses with the addition of other minor constitutes [56] as shown in Fig. 17. Bands in the $700-1100 \mathrm{~cm}^{-1}$ region are characteristic of $\mathrm{Si}^{-} \mathrm{O}^{-}$stretching vibrations in different $\mathrm{SiO}_{4}$ tetrahedron. Silica network is expressed in terms of $\mathrm{Q}^{n}$ structural units, where $\mathrm{Q}$ represents the $\mathrm{Si}$ tetrahedron and $n$ the number of bridging oxygen per tetrahedron. For silica network $n$ varies between 0 and 4 . Raman spectrum of glass SZS-1 has intense bands at $\sim 860,940$ and $1040 \mathrm{~cm}^{-1}$ and somewhat less intense, asymmetric band at $\sim 620 \mathrm{~cm}^{-1}$ and a weak band at around $360 \mathrm{~cm}^{-1}$. Based on the previous studies on silicate, borate and borosilicate glasses, bands at $\sim 940 \mathrm{~cm}^{-1}$ and $\sim 860 \mathrm{~cm}^{-1}$ are assigned to $\mathrm{Si}_{-}-\mathrm{O}^{-}$asymmetric stretching vibrations in $\mathrm{Q}^{2}$ and $\mathrm{Q}^{1}$ silicate structural units. Another band at around $1040 \mathrm{~cm}^{-1}$ is attributed to $\mathrm{Si}-\mathrm{O}$ vibrations of bridging oxygen (Si-O-Si) in different $\mathrm{Q}^{n}$ silicate structural units. With the addition of other constituents, intensity of band at $860 \mathrm{~cm}^{-1}$ increases and intensity of band at 940 and $1040 \mathrm{~cm}^{-1}$ decreases. This indicates that $\mathrm{Q}^{1}$ structural units are increasing and $\mathrm{Q}^{2}$ structural units are decreasing in the glass network [60-63]. Weak broad band at $\sim 360 \mathrm{~cm}^{-1}$ is attributed to rocking motion of silicate units and/or motion of cationic polyhedra [64]. New bands appeared in the Raman spectra of $\mathrm{B}_{2} \mathrm{O}_{3}$ containing glasses at $\sim 1200 \mathrm{~cm}^{-1}$ and $\sim 1450 \mathrm{~cm}^{-1}$. Intensity of these bands increases as concentration of $\mathrm{B}_{2} \mathrm{O}_{3}$ increases. Bands at $\sim 1200 \mathrm{~cm}^{-1}$ and $\sim 1450 \mathrm{~cm}^{-1}$ are attributed to vibrations of $\mathrm{B}-\mathrm{O}^{-}$ bond in triangular $\left(\mathrm{BO}_{3}\right)$ borate units [65-67]. The band appearing at $\sim 780 \mathrm{~cm}^{-1}$ in spectra of glass SZS-4 is assigned to vibrations of $\mathrm{B}-\mathrm{O}^{-}$bonds in tetragonal $\left(\mathrm{BO}_{4}\right)$ borate units [65-67]. This indicates that initially $\mathrm{B}_{2} \mathrm{O}_{3}$ is going into the network as triangular $\left(\mathrm{BO}_{3}\right)$ borate units and at higher concentration of $\mathrm{B}_{2} \mathrm{O}_{3}$ (as in glass SZS-4) a part of the $\mathrm{B}_{2} \mathrm{O}_{3}$ only goes into the glass network as tetragonal $\left(\mathrm{BO}_{4}\right)$ borate units. Thus Raman spectra revealed that glass network mainly composed of $\mathrm{Q}^{2}$ and $\mathrm{Q}^{1}$ silicate structural units. With the addition of $\mathrm{B}_{2} \mathrm{O}_{3}$ and other additives silicate glass network depolymerizes and concentration of $\mathrm{Q}^{1}$ structural units increases. These structural units are related to the crystalline phases of $\mathrm{Sr}_{2} \mathrm{ZnSi}_{2} \mathrm{O}_{7}$ and $\mathrm{SrSiO}_{3}$ developed in the glass matrix after heat treatment. It is known that generally $\mathrm{Q}^{1}$ units [i.e., $\left(\mathrm{Si}_{2} \mathrm{O}_{7}\right)^{-6}$ dimers] constitute sorosilicate crystalline phases like $\mathrm{Sr}_{2} \mathrm{ZnSi}_{2} \mathrm{O}_{7}$ and $\mathrm{Q}^{2}$ structural units [i.e., $\left(\mathrm{SiO}_{3}\right)^{-2}$ ] constitutes cyclosilicate and inosilicate phases like $\mathrm{SrSiO}_{3}$ [68]. Thus structural study of glasses indicate that presence of silicate structural units in the glass network decide the formation of crystalline phases during heat treatment. Therefore, with the addition of additives as $\mathrm{Q}^{1}$ units increases and $\mathrm{Q}^{2}$ units decreases, only $\mathrm{Sr}_{2} \mathrm{ZnSi}_{2} \mathrm{O}_{7}$ phase crystallize during heat treatment.

Adhesion behaviour of few glasses to YSZ was investigated. SEM image of the interface between YSZ and SZS-4 glass after heat treatment at $900{ }^{\circ} \mathrm{C}$ for $1 \mathrm{~h}$ in air ambient is shown in Fig. 21. Continuous interface shows good bonding between glass and YSZ. At interface elongated crystalline microstructure is also observed. Elemental line scans across interface (as presented in Fig. 21b) indicate that interdiffusion of Sr, 
Si from glass side to YSZ side and interdiffusion of Y, $\mathrm{Zr}$ from YSZ side to glass side is responsible for good bonding with YSZ. It is found that interfacial zone is around 3-4 $\mu \mathrm{m}$. Other investigated glasses have also shown good bonding with YSZ. Bonding behaviour of a few glasses with Crofer 22 APU was investigated. Figure 22a shows the SEM micrograph of the interface between Crofer 22 APU and SZS-6 glass after heat treatment at $950{ }^{\circ} \mathrm{C}$ for $1 \mathrm{~h}$ in air ambient. Smooth interface shows the good bonding between glass and Crofer 22 APU resulting from good wetting. Prismatic crystalline microstructure is observed at the interface. Interdiffusion of elements across the interface was

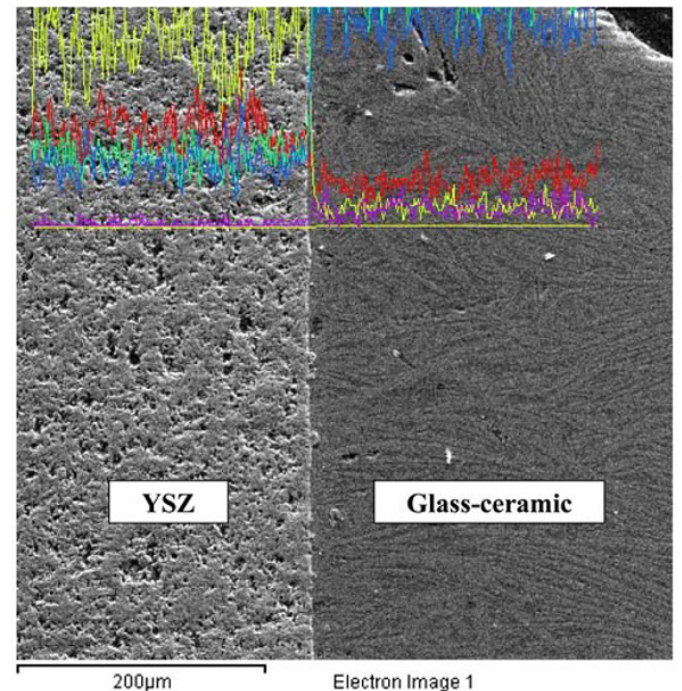

(a)

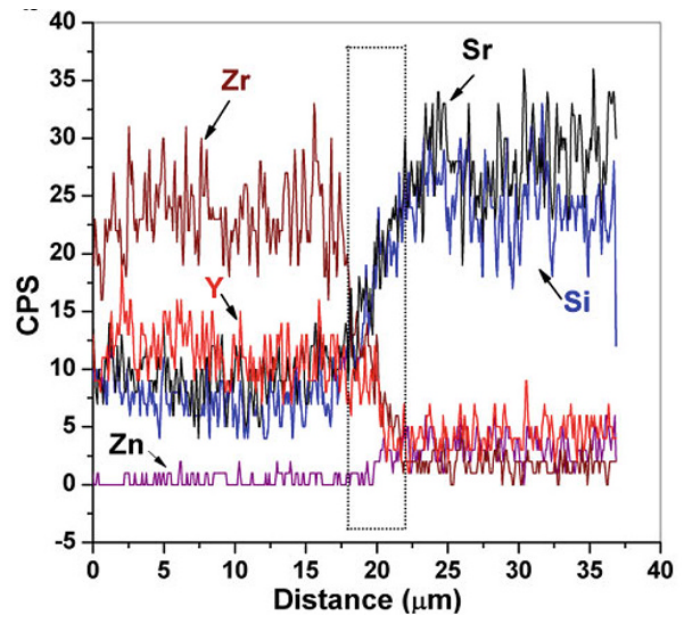

(b)

Fig. 21 (a) SEM micrographs of the SZS-4 glassceramic to YSZ interface after sealing at $950{ }^{\circ} \mathrm{C}$. (b) EDAX line scans across the interface showing the interdiffusion of $\mathrm{Si}, \mathrm{Sr}, \mathrm{Zr}$ and $\mathrm{Y}$ observed through elemental line scans as presented in Fig. 22b. These indicate that interdiffusion of $\mathrm{Cr}, \mathrm{Fe}$ from metal side to glass side and interdiffusion of $\mathrm{Si}$ from glass side to metal side takes place which is considered to be responsible for good bonding with Crofer 22 APU. Interfacial zone was found to be $\sim 4 \mu \mathrm{m}$. Seals of SZS-6 glass with Crofer 22 APU were leak tested at different elevated temperatures up to $950{ }^{\circ} \mathrm{C}$ in the steps of $100{ }^{\circ} \mathrm{C}$, for $30 \mathrm{~min}$ at each temperature. Seals were found to withstand a vacuum of $10^{-6}$ torr in the whole temperature range. This indicates the leak tightness of the seal at high temperatures.

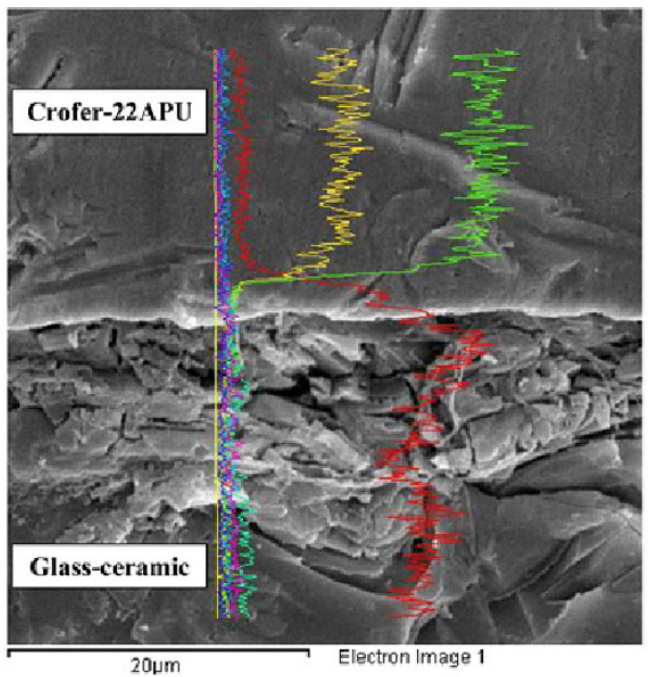

(a)

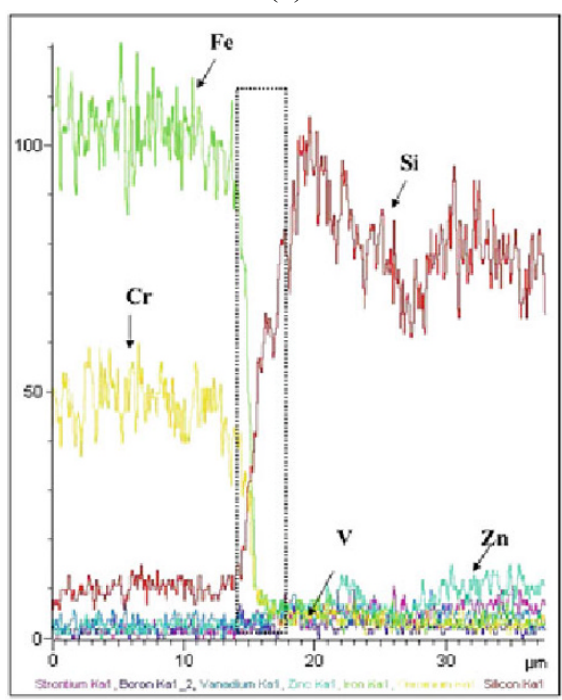

(b)

Fig. 22 (a) SEM micrographs of the SZS-6 glassceramic to Crofer 22 APU interface after sealing at $900^{\circ} \mathrm{C}$. (b) EDAX line scans across the interface showing the interdiffusion of $\mathrm{Fe}, \mathrm{Cr}$ and $\mathrm{Si}$ 


\section{Conclusions}

We have systematically investigated glasses belonging to the BCABS and SZS systems as potential SOFC sealants. In case of the BCABS glasses, poor interaction with YSZ motivated the incorporation of additives in order to augment wetting and interface behaviour. $\mathrm{P}_{2} \mathrm{O}_{5}$ was found to be most suitable as an additive and 1 mole $\% \mathrm{P}_{2} \mathrm{O}_{5}$ was found to be suitable for sealing. The incorporation of $\mathrm{P}_{2} \mathrm{O}_{5}$ helped in adhesion to Crofer-22 APU alloy by reaction with diffusing chromium leading to an interface saturated in $\mathrm{Cr}_{2} \mathrm{O}_{3}$. However, the problem of $\mathrm{Cr}$ diffusion and consequently the formation of $\mathrm{BaCrO}_{4}$ in an oxygen rich environment persist.

In order to prevent/minimize chromate formation at the interface, SZS glasses were investigated. Using a combination of Kissinger and the Matusita-Sakka method, it is found that SZS glasses phase separate into $\mathrm{SiO}_{2}$ and $\mathrm{ZnO}$ rich regions with $\mathrm{SrSiO}_{3}$ and $\mathrm{Sr}_{2} \mathrm{ZnSi}_{2} \mathrm{O}_{7}$ growing in these regions upon further heat treatment respectively. Upon further optimizing the SZS glasses using various additives, it is found that $\mathrm{B}_{2} \mathrm{O}_{3}$ allows a reasonable compromise between sealing properties, softening temperature and thermo-physical properties.

We are continuing to evaluate the properties of BCABS and SZS glasses with a focus upon long term stability, phase formation, interactions with other SOFC components and degradation behaviour under SOFC operating conditions. The studies carried out so far demonstrate the promise held by BCABS and SZS glass-ceramics as potential SOFC sealants and also the role played by complementary structural and thermophysical characterization in optimizing properties of glasses and glass-ceramics for challenging applications such as high temperature SOFC sealing.

\section{Acknowledgement}

The authors thank the IFCPAR for funding this work vide project number 4008-1. The FEDER, Region Nord Pas-de-Calais, Ministère de l'Education Nationale de l'Enseignement Supérieur et de la Recherche, CNRS, and USTL are acknowledged for funding of NMR spectrometers. One of the authors (AA) thanks the DAE for awarding him a fellowship. The technical support of L Burylo, N Djelal, V Alaimo and $\mathrm{S}$ Bellayer is gratefully acknowledged.

\section{References}

[1] Ananthanarayanan A, Kothiyal GP, Montagne L, et al. MAS-NMR studies of lithium aluminum silicate (LAS) glasses and glass-ceramics having different $\mathrm{Li}_{2} \mathrm{O} / \mathrm{Al}_{2} \mathrm{O}_{3}$ ratio. $J$ Solid State Chem 2010, 183: 120-127.

[2] Ananthanarayanan A, Kothiyal GP, Montagne L, et al. MAS-NMR investigations of the crystallization behaviour of lithium aluminum silicate (LAS) glasses containing $\mathrm{P}_{2} \mathrm{O}_{5}$ and $\mathrm{TiO}_{2}$ nucleants. $J$ Solid State Chem 2010, 183: 1416-1422.

[3] Ananthanarayanan A, Kumar R, Deo M N, et al. Preparation, structural and thermo-mechanical properties of lithium aluminum silicate glassceramics. Ceram Int 2009, 35: 1661-1666.

[4] Donald IW. Glass-to-Metal Seals. Sheffield, UK: Society of Glass Technology, 2009.

[5] Barbieri L, Corradi AB, Leonelli C, et al. Effect of $\mathrm{TiO}_{2}$ addition on the properties of complex aluminosilicate glasses and glass-ceramics. Materials Research Bulletin 1997, 32: 637-648.

[6] Beall GH. Design and properties of glass-ceramics. Annu Rev Mat Sc 1992, 22: 91-119.

[7] Best SM, Porter AE, Thian ES, et al. Bioceramics: Past present and for the future. J Eur Ceram Soc 2008, 28: 1319-1327.

[8] Tumala RR. Ceramic and glass-ceramic packaging in the 1990s. J Am Ceram Soc 2005, 74: 895-908.

[9] Kumar R, Arvind A, Goswami M, et al. The effect of $\mathrm{NiO}$ on the phase formation, thermo-physical properties and sealing behaviour of lithium zinc silicate glass-ceramics. J Mater Sci 2009, 44: 3349-3355.

[10] Lee YK, Choi SY. Crystallization and properties of $\mathrm{Fe}_{2} \mathrm{O}_{3}-\mathrm{CaO}-\mathrm{SiO}_{2}$ glasses. J Am Ceram Soc 1996, 79: 992-996.

[11] Sharma K, Dixit A, Bhattacharya S, et al. Effect of $\mathrm{ZnO}$ on phase emergence, microstructure and surface modifications of calcium phosphosilicate glass/glassceramics having iron oxide. Applied Surface Sciences 2010, 256: 3107-3115.

[12] Sharma K, Singh S, Prajapat CL, et al. Preparation and study of magnetic properties of silico phosphate glass and glass-ceramics having iron and zinc oxide. J Magnetism and Magnetic Materials 2009, 321: 3821-3828.

[13] Goswami M, Kothiyal GP, Montagne L, et al. MAS-NMR study of lithium zinc silicate glasses and glass-ceramics with various $\mathrm{ZnO}$ content. J Solid State Chem 2008, 181: 269-275.

[14] Guo X, Sun K, Yan Y, et al. Investigation on silver 
electric adhesive doped with $\mathrm{Al}_{2} \mathrm{O}_{3}$ ceramic particles for sealing planar solid oxide fuel cell. $J$ Power Sources 2009, 192: 408-413.

[15] Ley KL, Krumpelt M, Kumar R, et al. Glass-ceramic sealants for solid oxide fuel cells: Part I. Physical properties. J Mater Res 1996, 11: 1489-1493.

[16] Mahapatra M K, Lu K. Glass-based seals for solid oxide fuel and electrolyzer cells-A review. Mat Sci Eng $R$ 2010, 67: 65-85.

[17] Mahapatra MK, Lu K, Jr WTR. Thermophysical properties and devitrification of SrO- $\mathrm{La}_{2} \mathrm{O}_{3}-\mathrm{Al}_{2} \mathrm{O}_{3}-\mathrm{B}_{2} \mathrm{O}_{3}-\mathrm{SiO}_{2}$-based glass sealant for solid oxide fuel/electrolyzer cells. $J$ Power Sources 2008, 179: 106-112.

[18] Meinhardt KD, Kim DS, Chou YS, et al. Synthesis and properties of a barium aluminosilicate solid oxide fuel cell glass-ceramic sealant. $J$ Power Sources 2008, 182: 188-196.

[19] Menzler NH, Tietz F, Uhlenbruck S, et al. Materials and manufacturing technologies for solid oxide fuel cells. J Mater Sci 2010, 45: 3109-3135.

[20] Singh RN. Sealing technology for solid oxide fuel cells (SOFC). Int J Appl Cerm Technol 2007, 4: 134-144.

[21] Atkinson A, Sun B. Residual stress and thermal cycling of planar solid oxide fuel cells. Mat Sci Tech 2007, 23: 1135-1143.

[22] Bao C, Shi Y, Li C, et al. Multi-level simulation platform of SOFC-GT hybrid generation system. Int J Hydrogen Energy 2010, 35: 2894-2899.

[23] Hartman JS, Millard RL, Vance ER. A ${ }^{29} \mathrm{Si}$ magic angle spinning NMR study of vitreous and sol-gel precursors to sphene glass ceramics and their thermal crystallization. J Non-Cryst Solids 1989, 108: 49-57.

[24] Kazeempur P, Dorer V, Ommi F. Evaluation of hydrogen and methane-fuelled solid oxide fuel cell systems for residential applications: System design alternative and parameter study. Int $J$ Hydrogen Energy 2009, 34: 8630-8644.

[25] Kendall K, Singhal SC, Minh NQ. Cell and Stack Design. 1st Ed. Amsterdam, the Netherlands: Elsevier, 2003.

[26] Larsen PH, James PF. Chemical stability of $\mathrm{MgO} / \mathrm{CaO} / \mathrm{Cr}_{2} \mathrm{O}_{3}-\mathrm{Al}_{2} \mathrm{O}_{3}-\mathrm{B}_{2} \mathrm{O}_{3}$-phosphate glasses in solid oxide fuel cell environment. J Mater Sci 1998, 33: 2499-2507.

[27] Lee KH, Strand RK. SOFC cogeneration system for building applications, part 1: Development of SOFC system-level model and the parametric study. Renewable Energy 2009, 34: 2831-2838.

[28] Lee KH, Strand RK. SOFC cogeneration system for building applications, part 2: System configuration and operating condition design. Renewable Energy 2009, 34: 2839-2846.

[29] Al-Sulaiman FA, Dincer I, Hamdullahpur F. Exergy analysis of an integrated solid oxide fuel cell and organic Rankine cycle for cooling, heating and power production. J Power Sources 2010, 15: 2346-2354.

[30] Bengisu MK, Brow RK, Yilmaz E, et al. Aluminoborate and aluminoborosilicate glasses with high chemical durability and the effect of $\mathrm{P}_{2} \mathrm{O}_{5}$ additions on the properties. $J$ Non-Cryst Solids 2006, 352: 3668-3676.

[31] Chang HT, Lin CK, Liu CK. Effects of crystallization on the high-temperature mechanical properties of a glass sealant for solid oxide fuel cell. J Power Sources 2009, 195: 3159-3165.

[32] Fergus JW. Sealants for solid oxide fuel cells. $J$ Power Sources 2005, 147: 46-57

[33] Ghosh S, Sharma AD, Kundu P, et al. Development and characterizations of $\mathrm{BaO}-\mathrm{CaO}-\mathrm{Al}_{2} \mathrm{O}_{3}-\mathrm{SiO}_{2}$ glass-ceramic sealants for intermediate temperature solid oxide fuel cell application. $J$ Non-Cryst Solids 2008, 354: 4081-4088.

[34] Lara C, Pascaul MJ, Prado MO, et al. Sintering of glasses in the system $\mathrm{RO}-\mathrm{Al}_{2} \mathrm{O}_{3}-\mathrm{BaO}-\mathrm{SiO}_{2}(\mathrm{R}=\mathrm{Ca}$, $\mathrm{Mg}, \mathrm{Zn}$ ) studied by hot-stage microscopy. Solid State Ionics 2004, 170: 201-208.

[35] Ghosh S, Sharma AD, Kundu P, et al. Development and characterizations of $\mathrm{BaO}-\mathrm{CaO}-\mathrm{Al}_{2} \mathrm{O}_{3}-\mathrm{SiO}_{2}$ glass-ceramic sealants for intermediate temperature solid oxide fuel cell application. J Non-Cryst Solids 2008, 354: 4081-4085.

[36] Goel A, Tulyaganov DU, Pascaul MJ, et al. Development and performance of diopside based glass-ceramic sealants for solid oxide fuel cells. $J$ Non-Cryst Solids 2010, 356: 1070-1080.

[37] Wang SF, Wang YR, Hsu YF, et al. Effect of additives on the thermal properties and sealing characteristic of $\mathrm{BaO}-\mathrm{Al}_{2} \mathrm{O}_{3}-\mathrm{B}_{2} \mathrm{O}_{3}-\mathrm{SiO}_{2}$ glassceramic for solid oxide fuel cell application. Int $J$ Hydrogen Energy 2009, 34: 8235-8244.

[38] Sun T, Xiao H, Guo W, et al. Effect of $\mathrm{Al}_{2} \mathrm{O}_{3}$ content on $\mathrm{BaO}-\mathrm{Al}_{2} \mathrm{O}_{3}-\mathrm{B}_{2} \mathrm{O}_{3}-\mathrm{SiO}_{2}$ glass sealant for solid oxide fuel cell. Ceram Int 2010, 36: 821-826.

[39] Ananthanarayanan A, Kothiyal GP, Montagne L, et $a l$. The effect of $\mathrm{P}_{2} \mathrm{O}_{5}$ on the structure, sintering and sealing properties of barium calcium aluminum boro-silicate (BCABS) glasses. Mater Chem Phys 2011, 130: 880-889.

[40] Caurant D, Majerus O, Loiseau $\mathrm{P}$, et al. Crystallization of neodymium-rich phases in silicate glasses developed for nuclear waste immobilization. 
J Nuclear Mat 2006, 354: 143-162.

[41] Boccaccini AR, Hamann B. Review in Situ high-temperature optical microscopy. J Mater Sci 1999, 34: 5419-5436.

[42] Mackenzie KJD, Kemmitt T. Evolution of crystalline aluminates from hybrid gel-derived precursors studied by XRD and multinuclear solid-state MAS NMR I. Celsian, $\mathrm{BaAl}_{2} \mathrm{Si}_{2} \mathrm{O}_{8}$. Thermochimica Acta 1999, 325: 5-12.

[43] Yang Z, Meinhardt KD, Stevenson JW. Chemical compatibility of Barium-Calcium-Aluminosilicatebased sealing glasses with the ferritic stainless steel interconnect in SOFCs. J Electrochemical Soc 2003, 150: A1095-A1101.

[44] MacMillan PW. Glass-Ceramics. London, UK: Academic Press, 1979.

[45] Shelby JE. Introduction to Glass Science and Technology. Cambridge, UK: RSC, 2005.

[46] Tiwari B, Dixit A, Pillai CGS, et al. Crystallization kinetics and mechanism of strontium zinc silicate glass. J Am Ceram Soc 2012, 95:1290-1296.

[47] Kissinger HE. Variation of peak temperature with heating rate in differential thermal analysis. $J$ Res Nat Bur Stand 1956, 57: 217-221.

[48] Matusita K, Sakka S. Kinetic study on crystallization of glass by differential thermal analysis criterion on application of Kissinger plot. J Non-Cryst Solids 1980, 38-39: 741-746.

[49] Matusita K, Komatsu T, Yokota R. Kinetics of non isothermal crystallization process and activation energy for crystal growth in amorphous materials. $J$ Mater Sci 1984, 19: 291-296.

[50] Matusita K, Miura K, Komatsu T. Kinetics of non isothermal crystallization of some fluorozirconate glasses. Thermochim Acta 1985, 88: 283-288.

[51] Mazurin OV, Porai-Koshits EA. Phase Separation in Glass. Amsterdam, the Netherlands: North-Hollan Physics Publishers, 1984.

[52] Huntelaar ME, Cordfunke EHP, Scheele A. Phase relations in the Strontium Oxide-Silica-Zirconium dioxide system I. The system $\mathrm{SrO}-\mathrm{SiO}_{2}$. J Alloys Compd 1993, 191: 87-90.

[53] Ardit M, Cruciani G, Dondi M. The crystal structure of Sr-Hardystonite, $\mathrm{Sr}_{2} \mathrm{ZnSi}_{2} \mathrm{O}_{7}$. Z Kristallogr 2010, 225: 298-301.

[54] Tiwari B, Dixit A, Kothiyal GP. Study of glasses/ glass-ceramics in the $\mathrm{SrO}-\mathrm{ZnO}-\mathrm{SiO}_{2}$ system as high temperature sealant for SOFC applications. Int $J$ Hydrogen Energy 2011, 36: 15002-15008.

[55] Rao KJ. Structural Chemistry of Glasses. Amsterdam, the Netherlands: Elsevier, 2002.

[56] Pascual MJ, Guillet A, Duran A. Optimization of glass-ceramic sealant compositions in the system $\mathrm{MgO}-\mathrm{BaO}-\mathrm{SiO} 2$ for solid oxide fuel cells (SOFC). $J$ Power Sources 2007, 169: 40-47.

[57] Harada T, Takebe H, Kuwabara M. Effect of $\mathrm{B}_{2} \mathrm{O}_{3}$ addition on the thermal properties and structure of bulk and powdered barium phosphate glasses. $\mathrm{J} \mathrm{Am}$ Ceram Soc 2006, 89: 247-250.

[58] Goel A, Pascual MJ, Ferreira JMF. Stable glassceramic sealants for solid oxide fuel cell. Int $J$ Hydrogen Energy 2010, 35: 6911-6923.

[59] Tietz F. Thermal expansion of SOFC materials. Ionics 1999, 5: 129-139.

[60] Frantz JD, Mysen BO. Raman spectra and structure of $\mathrm{BaO}-\mathrm{SiO}_{2}, \mathrm{SrO}-\mathrm{SiO}_{2}$ and $\mathrm{CaO}-\mathrm{SiO}_{2}$ melts to 1600 C. Chem Geol 1995, 121: 55.

[61] Roy BN. Spectroscopic analysis of the structure of silicate glasses along the joint $\mathrm{xMAlO}_{2}-(1-\mathrm{x}) \mathrm{SiO}_{2}$ (M=Li, Na, K, Rb, Cs). J Am Ceram Soc 1987, 70: 183.

[62] Kamitsos EI, Kapoutsis JA, Jain H, et al. Vibrational study of the role of trivalent ions in sodium trisilicate glass. J Non-Cryst Solids 1994, 171: 31-45.

[63] Lin SL, Hawang CS. Structure of $\mathrm{CeO}_{2}-\mathrm{Al}_{2} \mathrm{O}_{3}-\mathrm{SiO}_{2}$ glasses. J Non-Cryst Solids 1996, 202: 61-67.

[64] Tiwari B, Pandey M, Sudarsan V, et al. Study of structural modification of sodium aluminophosphate glasses with $\mathrm{TiO}_{2}$ addition through Raman and NMR spectroscopy. Physica B 2008, 404: 47-51.

[65] Chryssikos GD. Bond length-Raman frequency correlation in borate crystals. J Raman Spectrosc 1991, 22: 645-650.

[66] Kamitsos EI, Karakassides MA, Chryssikos GD. Structure of borate glasses, part I: Raman study of cesium, rubidium and potassium borate glasses. Phys Chem Glasses 1989, 30: 229-234.

[67] Raluca CL, Ioan A. FTIR and Raman study of silver lead borate based glasses. J Non-Cryst Solids 2007, 353: 2020-2024.

[68] Holland W, Beall G. Glass-Ceramic Technology. Westerville, USA: The American Ceramics Society, 2002. 